IZADP No. 2995

Is the Chinese Growth Miracle Built to Last?

Eswar S. Prasad

August 2007 


\title{
Is the Chinese Growth Miracle Built to Last?
}

\author{
Eswar S. Prasad \\ Cornell University \\ and IZA
}

Discussion Paper No. 2995

August 2007

\author{
IZA \\ P.O. Box 7240 \\ 53072 Bonn \\ Germany \\ Phone: +49-228-3894-0 \\ Fax: +49-228-3894-180 \\ E-mail: iza@iza.org
}

\begin{abstract}
Any opinions expressed here are those of the author(s) and not those of the institute. Research disseminated by IZA may include views on policy, but the institute itself takes no institutional policy positions.

The Institute for the Study of Labor (IZA) in Bonn is a local and virtual international research center and a place of communication between science, politics and business. IZA is an independent nonprofit company supported by Deutsche Post World Net. The center is associated with the University of Bonn and offers a stimulating research environment through its research networks, research support, and visitors and doctoral programs. IZA engages in (i) original and internationally competitive research in all fields of labor economics, (ii) development of policy concepts, and (iii) dissemination of research results and concepts to the interested public.
\end{abstract}

IZA Discussion Papers often represent preliminary work and are circulated to encourage discussion. Citation of such a paper should account for its provisional character. A revised version may be available directly from the author. 


\section{ABSTRACT}

\section{Is the Chinese Growth Miracle Built to Last?*}

Is the Chinese growth miracle - a remarkably high growth rate sustained for over two decades - likely to persist or are the seeds of its eventual demise contained in the policies that have boosted growth? For all its presumed flaws, the particular approach to macroeconomic and structural policies that has been adopted by the Chinese government has helped to deliver high productivity and output growth, along with a reasonable degree of macroeconomic stability. In tandem with a benign international environment, this approach makes it unlikely that the economy will face a collapse in growth. But there comes a point when the policy distortions needed to maintain this approach could generate imbalances, impose potentially large welfare costs, and themselves become a source of instability. The traditional risks faced by emerging market economies, especially those related to having an open capital account, do not loom large in the case of China. In the process of securing protection against external risks, however, Chinese policymakers may have increased the risks of internal instability. There are a number of factors that could trigger unfavorable economic dynamics that, even if they don't rise to the level of a crisis, could have serious adverse repercussions on growth and welfare. The flexibility and potency of macroeconomic tools to deal with such negative shocks is constrained by the panoply of policies that has supported growth so far.

JEL Classification: F3, E5, O1

Keywords: macroeconomic policies, exchange rate flexibility, capital account liberalization, financial sector reforms

Corresponding author:

Eswar S. Prasad

Department of Applied Economics and Management

Cornell University

440 Warren Hall

Ithaca, NY 14853

USA

E-mail: eswar.prasad@cornell.edu

\footnotetext{
*Earlier versions of this paper were presented at the American Enterprise Institute, the China Banking Regulatory Commission, the People's Bank of China, the China Center for Economic Research at Peking University, and the EBRD. I thank Philip Levy, Justin Lin, Luo Ping, Li Ruogu, Andrew Sheng and numerous other colleagues for useful discussions and comments. I am grateful to Sun Tao for help in obtaining some of the data used in this paper. Rahul Anand and Wellian Wiranto provided able research assistance.
} 


\section{Overview}

The Chinese economy has been humming along for over two decades now, with no sign of slowing down anytime soon. The economy held together well even during the tumultuous period of the Asian crisis in the late 1990s. Since then, annual GDP growth has averaged about 10 percent and, after a brief flirtation with deflation during 2002-03, inflation has begun creeping up but remains moderate, with the recent spikes in CPI inflation largely attributable to food price increases (Figure 1).

This remarkable macroeconomic success has given rise to two opposing views about prospects for the Chinese economy. One is that all is well-indeed, in some ways things may be even better than they look-and, with some minor policy adjustments, there is no reason the party (the economic one, that is) cannot go on indefinitely. The other view is that the economic boom is built on a house of cards that could come crashing down any minute. Where should we place our bets? Is the economy fundamentally strong or just pumped up on steroids?

Even a casual reader of economic history knows that apparently sure things, borne along on the belief that this time things are really different, often come unhinged with little warning. But perhaps things really are different this time. While the Chinese growth miracle has borrowed part of its template from other success stories, there are many aspects to the Chinese experience that do make it sui generis. For instance, the investment boom that has underpinned growth has been largely financed out of domestic savings, the stock of foreign exchange reserves is well beyond any reasonable precautionary norms and--despite the huge capital inflows during 2001-05, booming trade surpluses in the last two years, and the rapid rate of expansion of monetary and credit aggregates--there are few signs of major inflationary pressures in core price indicators.

In this paper, I will argue that things are indeed different in the sense that China's present situation makes a growth collapse unlikely. However, this is not to say that all is well. There are deep structural problems in the economy that Chinese policymakers need to come to grips with. A high rate of growth is of course one of the best tonics for such problems as they diminish their scale in relative terms and also create resources to deal with them. Perhaps, therefore, the means to achieving high growth may be less relevant than the end results.

But rapid growth can hide, or in some cases even exacerbate, a number of problems that come home to roost when the going gets rough, as it has a habit of doing. For instance, the financial sector is in poor shape and has distorted domestic demand; the patterns of investment financing could lead to a resurgence of nonperforming loans (NPLs) in the future and, by fueling a buildup of excess capacity in some sectors, could generate deflationary risks in the medium term. Meanwhile, in the short term, some of the pressures are becoming evident in other forms such as asset price booms (in the equity markets, in particular). 
In my view, however, the sustainability of growth--while an important concern--is not the key problem. There are indirect and subtle costs to the current growth model that deserve far more attention. For instance, China has held the exchange rate of the renminbi relative to the U.S. dollar within a narrow range despite enormous pressures for a substantial appreciation in recent years. And this has been accomplished without the typical rising quasi-fiscal costs of sterilizing the liquidity generated by large capital inflows. But sterilization has been facilitated by financial repression and a relatively closed capital account. This has, among other things, meant very low real rates of return for households, who save a lot and have few investment opportunities other than domestic bank deposits. These policies have also curtailed financial sector development, leading to inefficient intermediation of domestic capital. There are clearly large welfare costs associated with these constraints.

The second issue, which looms larger in my mind, is that the growth strategy has involved a number of policy distortions and constraints that have greatly reduced the room for policy maneuver in case any big shocks should hit. It is inevitable that, as the economy becomes more complex and integrated with the world trade and financial systems, it will be exposed to more shocks. Such shocks could come from internal sources-e.g., loss of confidence in the banking system, social instability generated by rising inequality - or external sources-e.g., international capital market crises, a collapse of external demand, U.S. trade sanctions, flaring-up of tensions over Taiwan etc.

Of course, shocks tend to mutate into forms that one cannot predict and often come from unexpected directions. Chronicles of crises foretold are far outnumbered by crises that were largely unanticipated until things began to unravel. Thus, a more relevant question than the one about sustainability on the basis of purely internal dynamics of the system is whether the economy has enough flexibility to withstand and recover from large shocks, either internal or external. Here the answer is far less clear.

Monetary policy is typically the first line of defense against such shocks but, with monetary policy constrained by the objective of maintaining a tightly managed exchange rate, it can at best play a very limited role. There appears to be room for fiscal maneuver since the explicit levels of the fiscal deficit and government debt are quite low (Figure 2), but this may be deceptive as there are large contingent liabilities in the state-owned banking system and huge unfunded pension liabilities. The financial system is still dysfunctional in many ways and may not be deep or robust enough to withstand a significant shock.

So what should China do to prepare itself to deal with shocks, and make growth more balanced and sustainable? There are some answers that few would disagree with. The banking system should be made more robust and driven by market principles, and the financial system should be broadened to create alternative sources of funding for firms and alternative investment opportunities for households and firms. The state-owned enterprise sector needs to be further corporatized by hardening budget constraints. There is a need for a better social safety net and a better system for delivery of social services. 
While it is easy to create an even longer laundry list of reforms, a key point is that many of these reforms are inter-related and China has reached a point in its evolution towards a major market-oriented economy that trying to implement these reforms in isolation is not an effective way to proceed. For instance, stable macroeconomic policies and a welldeveloped and efficient financial sector are essential ingredients for balanced and sustainable growth. In turn, these two intermediate objectives would be helped by effective monetary policy and further capital account liberalization. And a flexible exchange rate is a prerequisite for both of these.

Ignoring these linkages - for instance, trying to push forward with banking reforms while holding monetary policy hostage to an exchange rate objective-makes an already difficult reform process even harder. Similarly, financial repression has kept the real price of capital cheap and, along with subsidized energy and land prices, shifted production towards capital-intensive methods. This works at cross-purposes with the authorities' goal of boosting employment growth and facilitating the transition of rural unemployed and underemployed to employment in manufacturing and services.

Before one gets swept away by doom and gloom scenarios, however, it is also important to recognize some of the intrinsic strengths of the system. While the state sector remains dominant, there is a vibrant and rapidly expanding private sector that, despite all of its own flaws, is probably contributing even more to output and employment growth than suggested by official statistics. There has also been significant reform of the state-owned enterprise and banking sectors. There is a long way to go on reform of these sectors but, given the legacy problems that they faced to begin with and the apparent intractableness of the root problems, such progress cannot be dismissed as being inconsequential. There are other structural features of the economy that also constitute key strengths-a labor market that is flexible in many dimensions, a physical infrastructure that is the envy of many countries at a similar stage of development, an economy that is very open to trade, and a highly competitive export sector. Indeed, all of these factors come together in delivering the apparently high rate of productivity growth and subdued inflation.

Ultimately, the essence of the policy debate can be framed in terms of the pace and sequencing of reforms required to turn these strengths into forces that allow the growth miracle to be sustained and to reduce the risks of its being derailed by shocks. There is, as always a delicate balance to be struck in terms of the reform strategy; economic theory by itself is of little practical value here as it points out the first best but not the least risky way to get there.

One key principle, as noted above, is to recognize that there are inherent limits to the incremental reform strategy that has worked well in the past. At a certain level of development and complexity of an economy, the connections among different reforms become difficult to ignore. There is also the pressing need to take advantage of favorable conditions that now exist--high growth, low inflation, a benign international environment--to push forward with reforms that could be much messier and more difficult to implement under duress when times are not as good. 


\section{Parsing the Growth Story}

One dimension of the Chinese growth story that is of particular relevance in the context of the arguments in this paper is the composition of growth. Until recently, data on the composition of GDP from the expenditure side were available only on a nominal basis. To provide a historical comparison, I present those data here. Figure 3 shows that investment has been a major contributor to growth during this decade, in some years accounting for nearly two-thirds of nominal GDP growth. It is also worth noting that net exports by themselves were not a major contributor to growth for most of this decade. Even though Chinese exports have been growing by leaps and bounds, the direct growth contribution of the trade balance had been relatively small until 2005-6.

For a developing economy that is typically labor-rich but capital-poor, high rates of investment ought to be good for faster capital accumulation and higher growth during the convergence to the steady state rate of long-run growth. But a substantial fraction of this investment in China has been financed by credit provided by state-owned banks at low interest rates. Indeed, cheap capital has played a big part in skewing the capital-labor ratio and holding down employment growth (Aziz, 2006). In addition, local governments provide subsidized land in order to encourage investment. And energy prices continue to be administered and made available to enterprises at prices below international levels. Hence, the prices of the factors of production that serve as complementary inputs to physical capital — land and energy — are also cheap. Consequently, the government has not been able to cool off investment growth in recent years despite fears of overheating and the investment to GDP ratio has remained above 40 percent (Figure 4).

One consequence of the investment-heavy expansion has been the relatively slow employment growth. It is nowhere near a pace sufficient to keep up with the growth in the labor force, absorb workers laid off from state enterprises that are retrenching, and also absorb excess rural labor (which some policymakers have speculated could be on the order of 150 million persons, nearly half of the rural workforce) ${ }^{2}$ Indeed, during the period 2000-05, growth of total non-agricultural employment averaged less than 3 percent per annum (see the last column in Table 1), compared to average non-agricultural GDP growth of about 9.5 percent (Table 2).

There are two features of bank lending that may be relevant for the price of capital-the first is the lending rate. Recent increases in the base lending rate have been far too small to raise the real price of capital to a meaningful level for an economy that is experiencing annual real growth of over 10 percent (Figure 5). The second factor is the absence of obvious penalties for nonrepayment of loans by state-owned enterprises, which has effectively acted as a further subsidy for capital. This factor has become less relevant over time as state enterprises are being subject to increasingly hard budget constraints and banks' NPL positions are being closely monitored.

\footnotetext{
${ }^{2}$ See the chapter by Brooks in Prasad (ed., 2004) for some detailed calculations.
} 
The ceiling on lending rates had acted as a direct instrument for subsidizing capital. Following gradual increases in the lending rate, in October 2004 the ceiling on lending rates was scrapped altogether (except for urban and rural credit cooperatives). ${ }^{3}$ The subsequent widening of the gap between the base lending rate and the actual lending rate (a weighted average based on loan volumes) indicated that banks were beginning to use this margin (Figure 6). However, this margin has shrunk recently and there is little evidence that the large state commercial banks (SCBs), in particular, are using this flexibility to substantially redirect lending to the private sector at higher interest rates.

Results of surveys of lending institutions reported in the People's Bank of China's quarterly Monetary Policy Reports reveal that banks still price a majority of their loans around the base lending rate (which has now become a floor). ${ }^{4}$ This could in part reflect concerns banks have about their own risk-assessment capabilities, especially in an environment where there is still strong pressure to avoid accumulation of new NPLs. A less benign explanation is that banks are responding to an informal incentive structure that remains unchanged-loans made to state enterprises are still regarded as less risky in terms of reputational costs to bank managers and loan officers, while loans made to private sector enterprises that become nonperforming could entail charges of incompetence or corruption. ${ }^{5}$ Deficiencies in the legal framework may also play a role. Weak legal protection means that collateral provisions are difficult to enforce, so lending to the private sector carries additional risks.

A lot of the recent investment has also been financed through retained earnings; such investment is surely reasonable as it is being undertaken by profitable firms. However, even here the picture is far from clear. Profitable state enterprises were not, until very recently, required to pay dividends to the state. This suggests that such investment may have been spurred by the minimal rates of return on bank deposits which made even marginal investment projects seem in the money. The risk, of course, is that such high rates of investment in industries with favorable demand conditions may be leading to a buildup of excess capacity in those very industries; this could become evident if there were to be adverse demand shocks in the future (Goldstein and Lardy, 2006).

\footnotetext{
${ }^{3}$ Dunaway and Prasad (2004) note the potential benefits of this policy shift.

${ }^{4}$ State-owned commercial banks, joint-stock commercial banks and policy banks accounted for about three-quarters of all RMB loans made by domestic banks in 2006. In the fourth quarter of 2006, about 98 percent of the loans made by these three groups of banks were at an interest rate no higher than 1.3 times the base lending rate-i.e., below 9 percent even for long-term loans (see Tables 1 and 2 in the PBC Monetary Policy Report, 2006Q4).

${ }^{5}$ Anecdotal evidence suggests that bank lending has become increasingly skewed towards large enterprises, which are of course mostly state-owned. Podpiera (2006) examines lending growth, credit pricing, and regional patterns in lending to look for evidence of changes in the behavior of SCBs following recent reforms and strengthening of their balance sheets. He concludes that the pricing of credit risk remains rather undifferentiated and that SCBs do not appear to take enterprise profitability into account when making lending decisions. Dobson and Kashyap (2006) discuss some of the challenges of banking reforms in China.
} 
While investment has been high, national savings have been even higher, with both household and corporate savings rising in recent years. The uncertainties engendered by the transition to a market economy, the limited availability of instruments to borrow against future income to finance purchases (major durable goods, housing etc.), and the lack of international portfolio diversification opportunities have all contributed to high household savings (Chamon and Prasad, 2007). Financial system repression has meant that there are few alternatives to funneling these savings into deposits in the state-owned banking system (Figure 7).

Households willingly hold bank deposits despite the weaknesses of the banking system because of implicit deposit insurance provided by the government. This provides abundant liquidity for banks to expand credit which, because of the distorted incentives faced by lenders, largely finances investment by state enterprises. State enterprises that do make profits are not required to pay dividends, encouraging them to plow retained earnings (which are counted as enterprise savings) back into investment. Thus, the investment boom in recent years has been fueled by cheap credit and overoptimistic expectations of future demand growth in sectors that are doing well at present.

As for manufacturing exports, Chinese policymakers clearly see them as an integral part of the growth strategy. Policy measures to encourage exports include (until very recently) substantial tax incentives for foreign direct investment into China-most of this FDI has gone into the exporting sector-and the setting-up of special economic zones for exporting firms. Export growth skyrocketed after China's WTO accession in 2001, which opened up industrial country markets that had previously restricted imports from China. It is estimated that about half of China's exports are accounted for by processing trade, which accounts for only limited value added to final products within China. However, far more important than the direct contribution of the trade balance to GDP may have been the catalytic effect of gross exports, especially the technological and efficiency gains that have come with greater outward orientation of the economy.

\section{Policy Choices and Their Consequences}

I now turn to a discussion of economic policy choices that, unwittingly or otherwise, have generated the patterns of growth described above. China's currency policy has of course received the most attention of late. Whether the maintenance of a fixed exchange rate is part of a deliberate mercantilist strategy to promote export-led growth has been the subject of intense debate. On the one hand, China has had a relatively stable exchange rate relative to the U.S. dollar since 1995. This policy was sustained even through the Asian crisis when the temptations for devaluing the currency were great.

On the other hand, during this decade the exchange rate has been kept from appreciating only by massive intervention in the exchange market. In tandem with sustained high export growth and a burgeoning current account surplus that nearly hit 10 percent of GDP in 2006 (Figure 8 and Table 3), this has been seen as prima facie evidence of a grossly undervalued currency. Determining the extent of undervaluation of the renminbi is, 
however, not an easy matter. ${ }^{6}$ In any event, there are clearly huge underlying pressures for real exchange rate appreciation coming from China's high productivity growth in its traded goods sector relative to that of its trading partners. ${ }^{7}$ Despite these pressures, as Figure 9 shows, the real effective exchange rate of the renminbi is now below its recent peak in 2002 (largely due to the U.S. dollar's depreciation against other major currencies).

What has accounted for the surge in the accumulation of international reserves since 2001 (Figure 10)? Table 4 shows that, during the period 2001-04, inflows of speculative capital (in anticipation of eventual renminbi appreciation) accounted for most of the pickup in the pace of reserve accumulation relative to the period 1998-00. During 2005-06, speculative inflows shrank but the slack was more than taken up by a dramatic surge in the trade balance, which pushed up the rate of reserve accumulation to double the rate during 2001-04. The inflows resulting from these factors have added to the liquidity in the banking system and further complicated the control of credit growth (Figure 11)

Why have these inflows not led to rampant inflation? The answer lies in the ability of the PBC to sterilize these inflows. Such sterilization usually quickly runs into limits in most emerging market economies. Government bonds that are used to soak up liquidity have to offer increasingly high yields to convince domestic economic agents to hold them, leading to ever-increasing costs to the budget.

In the case of China, however, a confluence of forces appears to have made sterilization operations relatively easy to carry out. As noted earlier, private saving rates (both household and corporate) continue to be very high; most of these savings invariably flow into the banking system since there are few alternatives. This has made the banks flush with liquidity, particularly at a time when they are under pressure to hold down growth in credit. Despite a number of recent increases in the required reserves ratio, the banking system as a whole still has a sizeable chunk of excess reserves at the PBC (Figure 12a). The PBC has been cutting the rate of remuneration on excess reserves (now at 0.99 percent) in order to discourage banks from holding excess reserves at the $\mathrm{PBC}$ as they reduce the efficacy of the monetary transmission mechanism (Figure 12b).

The state commercial banks have also been aggressively trying to improve their balance sheets, including in terms of meeting capital adequacy norms set by the government, in order to attract strategic investors and undertake successful IPOs. In this context, banks have an incentive to hold PBC bills rather than increase their lending since corporate lending, for instance, carries a capital requirement of 100 percent while no capital needs to be put aside for lending to the government. Thus, there is a great deal of demand for PBC bills even at relatively low interest rates.

\footnotetext{
${ }^{6}$ See Goldstein (2005), Frankel (2006), Dunaway, Leigh and Li (2006), and Cheung, Chinn and Fujii (2007) for a range of views on this subject.

${ }^{7}$ Bosworth and Collins (2007) and Perkins and Rawski (2007) conduct growth accounting exercises and provide estimates of Chinese productivity growth.
} 
Between the increases in reserve requirements and open market operations, the PBC has been able to mop up a lot of liquidity, although the stock of outstanding PBC bills has now grown quite large and the $\mathrm{PBC}$ is constantly playing catch-up with the liquidity pouring into the banking system (Figure 13). ${ }^{8}$ Nevertheless, yields on PBC bills remain well below the rates of return on comparable-maturity industrial country treasury bonds (Figure 14). This means that, at the margin, sterilization is essentially a moneymaking operation for the PBC.

But such a cost-benefit calculation can be deceptive. As discussed in more detail below, one of the principal concerns is that the lack of exchange rate flexibility not only reduces monetary policy independence, it also hampers banking sector reforms. The inability of the PBC to use interest rates as a primary tool of monetary policy implies that credit growth has to be controlled by blunter and non-market-oriented tools, including targets/ceilings for credit growth as well as "non-prudential administrative measures" (which effectively amount to moral suasion). Prasad and Rajan (2006) argue that this vitiates the process of banking reform by keeping banks' lending growth under the administrative guidance of the PBC rather than letting it be guided by market signals. This constraint has also perpetuated large efficiency costs via provision of cheap credit to inefficient state enterprises (Dollar and Wei, 2007). The incidence of these and other costs of banking system inefficiency are not obvious, but they may ultimately be borne by depositors in the form of low (or negative) real returns on their saving. ${ }^{9}$

The management of capital flows has been another crucial component of macroeconomic policy. Extensive capital controls, along with tax benefits and other incentives, have been used to promote inward FDI while other forms of inflows, especially portfolio debt, have been discouraged (Prasad and Wei, 2007). Capital controls have also played an important role in protecting the banking system from external competition by restricting the entry of foreign banks and by making it harder to take capital out of the country. The limited development of debt and equity markets means that the state-owned banking system is effectively the only major game in town, for both borrowers and savers.

China's approach to exchange rate policy and capital account liberalization may be indicative of a desire to maintain stability on the domestic and external fronts while opening up to trade and financial flows. And the large stock of foreign exchange reserves resulting from these policies may serve as insurance against vulnerabilities arising from a weak banking system. ${ }^{10}$ But there comes a point when the policy distortions needed to maintain this approach could generate imbalances, impose potentially large welfare costs, and themselves become a source of instability.

\footnotetext{
${ }^{8}$ Since total deposits in the banking system amount to about 34 trillion yuan ( $\$ 4.5$ trillion), a 1 percentage point increase in the required reserves ratio locks down about $\$ 45$ billion.

${ }^{9}$ In July 2007, the benchmark one-year deposit rate was raised to 3.33 percent and the tax rate on bank interest income was cut from 20 percent to 5 percent. The effective after-tax deposit rate is now 3.16 percent, which is still below the current rate of CPI inflation.

10 Jeanne (2007) argues that the level of reserves now held by China far exceeds any reasonable calculation of what is needed for precautionary reasons.
} 


\section{Connections among Different Reforms}

What is the way forward? It turns out that it is not easy to isolate specific policies to deal with particular problems identified above. Indeed, the reform process appears to have reached a stage where the traditional approach of undertaking incremental reforms in isolation from others may not work well anymore. ${ }^{11}$ Given the prominence of China's exchange rate regime in discussions about China-U.S. bilateral relations as well as the issue of global current account imbalances, currency policy provides a good illustration about the inter-connectedness of various reforms.

To begin with, why is the exchange rate regime of such importance? After all, the exchange rate is just a relative price. Moreover, economic models tell us that macroeconomic fundamentals will eventually win out in terms of what really mattersthe real exchange rate rather than the nominal exchange rate. That is, if the nominal exchange rate doesn't adjust in response to changes in fundamentals, relative price levels will adjust. But a combination of policies such as financial repression and a closed capital account can delay this adjustment for a significant period. While this can boost export competitiveness by keeping the exchange rate undervalued, there can be subtle indirect costs, in terms of both economic welfare and reduced policy flexibility in responding to various shocks.

What are the costs of an inflexible exchange rate? The schematic diagram below lays out some of the connections, although this should of course be recognized as a heuristic diagram that ignores many of the complexities in the relationships depicted here. The main point is that an inflexible exchange rate, while not the root cause of imbalances in the economy, requires a large set of distortionary policies for its maintenance over long periods. It is these distortions that-through multiple channels-hurt economic welfare and could, over time, shift the balance of risks in the economy.

\footnotetext{
${ }^{11}$ See Blanchard and Giavazzi (2006) and Prasad and Rajan (2006) for more on this point.
} 


\section{Lack of Exchange Rage Flexibility Complicates Macro Policy and Reforms}

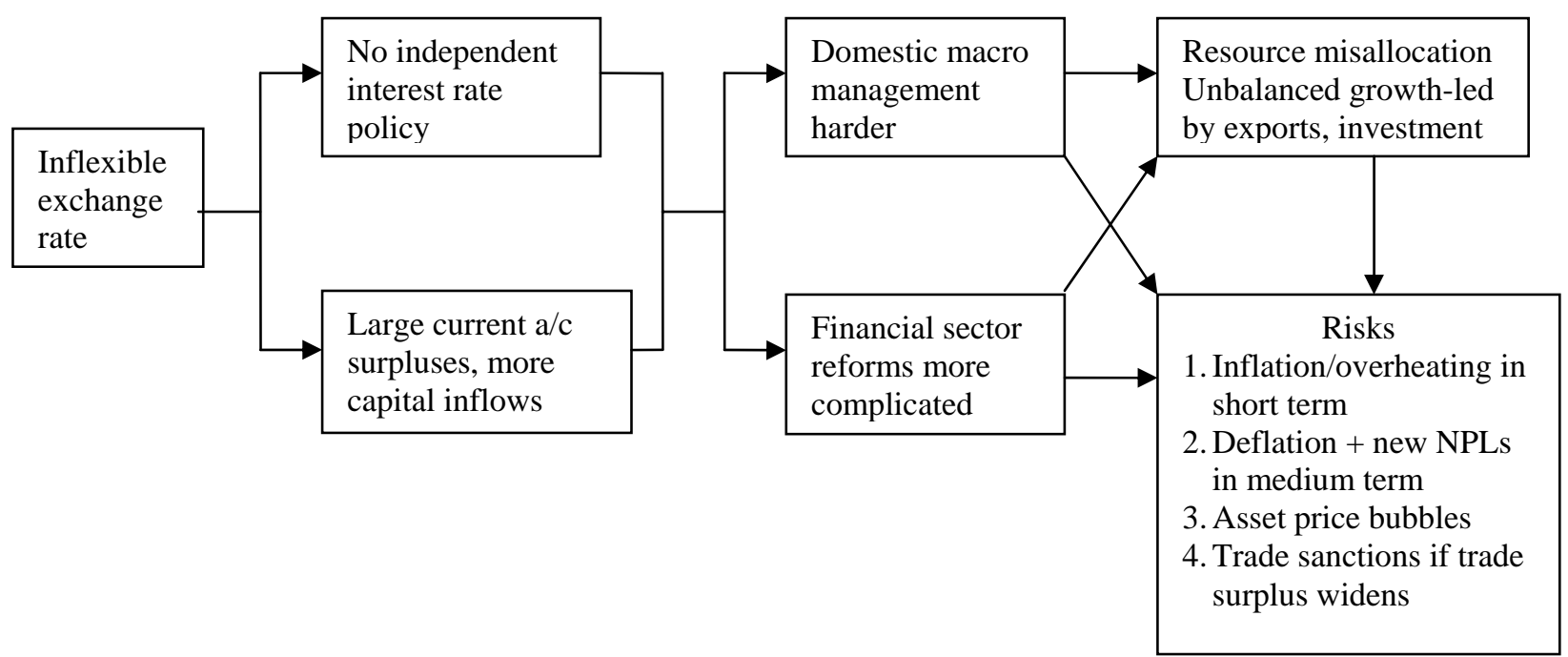

Flipping this around makes it easier to see why exchange rate flexibility matters for China. It is not because it will directly have a large or lasting impact on problems such as the U.S.-China trade imbalance. ${ }^{12}$ Rather, the case for a flexible exchange rate rests on a deeper set of policy priorities, with the ultimate objective being balanced and sustainable growth in the longer term.

\section{Making the Right Connections}

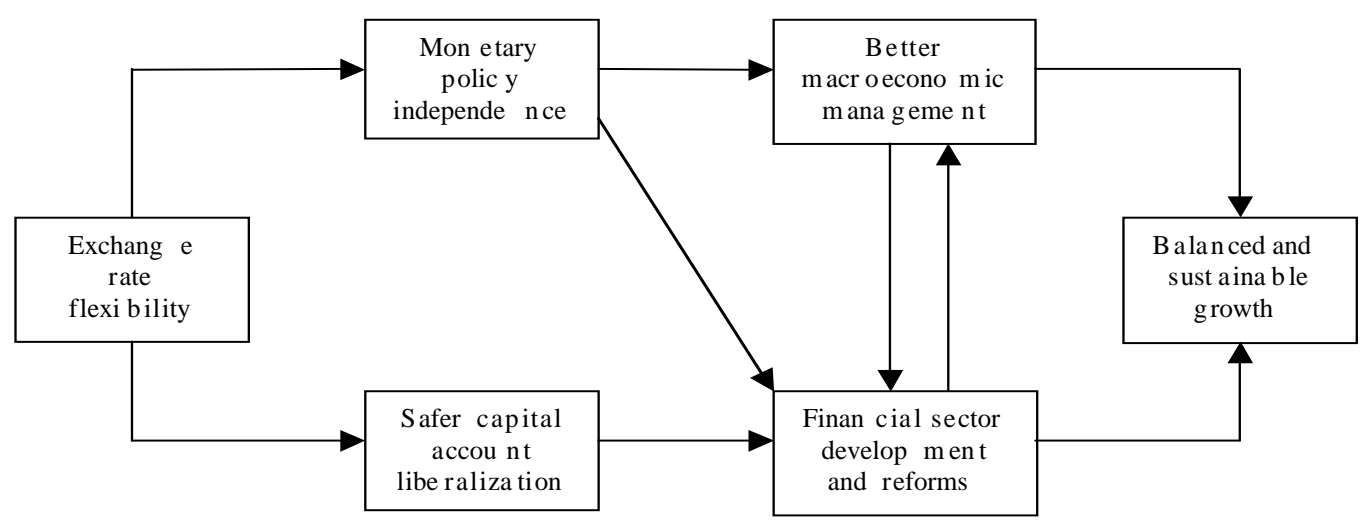

\footnotetext{
${ }^{12}$ While Chinese currency appreciation by itself may not have much of an impact on global current account imbalances either, it would be an important step towards resolving those imbalances since other Asian economies may be emboldened to allow their currencies to appreciate as well if China made the first move.
} 
An independent interest rate policy is a key tool for improving domestic macroeconomic management and promoting stable growth and low inflation. As the Chinese economy becomes more complex and market-oriented, it will become harder to manage through command and control methods as in the past. And, as it becomes more exposed to global influences through its rising trade and financial linkages to the world economy, it will also become more exposed to external shocks. Monetary policy is typically the first line of defense against macroeconomic shocks, both internal and external. Hence, having an independent monetary policy is important for overall macroeconomic stability.

Monetary policy independence is, however, a mirage if the central bank is mandated to attain an exchange rate objective. Capital controls, which prevent money from moving in an out of an economy easily, do insulate monetary policy to some extent. But capital controls are notoriously leaky (the unofficial flows into and out of China itself are ample testimony to this) and tend to become increasingly less effective over time. ${ }^{13}$ Thus, a flexible exchange rate is a prerequisite for an independent monetary policy.

Independent interest rate policy, in turn, is a key input into financial sector reforms. Until the late-1980s, lending operations of state-run banks (which still dominate the financial landscape in China) were determined by the government. The legacy of directed lending lives on in some ways, especially since Chinese banks have still not developed riskassessment expertise or been given the right incentives to lend on commercial principles. Thus, using interest rate policy, rather than government directives, to guide credit expansion is essential to encourage banks to become more robust financial institutions. Trying to foster the commercial orientation of the banking sector in the absence of monetary policy tools to guide credit and money growth vitiates banking reforms.

The argument that the financial system needs to be fully modernized before allowing currency flexibility therefore has it backwards. Indeed, durable banking reforms are likely to be stymied if the PBC's ability to manage interest rates is constrained by the exchange rate objective. The $\mathrm{PBC}$ then has to revert to its old practice of telling state banks how much to lend and to whom, which hardly gives banks the right incentives to assess and price risk carefully in their loan portfolios. This makes banking reforms even more complicated than they already are.

Another requirement for broader financial development is a stable macroeconomic environment, for which again good macroeconomic policies, including effective monetary policy, are necessary. On the flip side, the lack of effective macroeconomic management could generate risks via the financial sector. In the absence of room for maneuver on interest rates, liquidity flows into the economy could result in asset price bubbles, including in the real estate and stock markets. These markets could become

${ }^{13}$ A crude way of measuring net flows through unofficial channels is to look at the errors and payments category of the balance of payments. Prasad and Wei (2007) document that, during periods of downward (depreciation) pressures on the renminbi-e.g., the Asian crisis perioderrors and omissions were negative and large, suggesting significant capital flight. During 200305 , the errors and omissions turned into large positive numbers, reflecting speculative inflows in anticipation of renminbi appreciation. Gross unofficial flows could of course be much larger. 
vulnerable to sudden and unpredictable shifts in investor sentiment that could send them tumbling at the slightest provocation, with broader ripple effects through the economy.

For developing the domestic financial sector, opening up of the capital account- to inflows as well as to outflows - could also serve as an important catalyst. ${ }^{14}$ Inflows can bring in technical expertise on developing new financial instruments, creating and managing risk assessment systems, and improving corporate governance. Indeed, the approach of using foreign strategic investors to improve the efficiency of domestic banks is a strategy the Chinese authorities see as playing a useful role in their overall reform effort. Allowing outflows would help increase efficiency by creating competition for the domestic banking system and limiting the captive source of funds (bank deposits) that now keep domestic banks flush with liquidity.

However, opening the capital account ahead of introducing greater flexibility in the exchange rate could pose serious problems in the future. ${ }^{15}$ History is replete with examples of countries that opened up the capital account while things looked good, even while keeping their exchange rates fixed, and were then subject to large exchange rate depreciations when they were subject to sudden stops and/or reversals of capital flows.

Ultimately, stable macroeconomic policies and a well-developed and efficient financial sector are crucial ingredients for balanced and sustainable growth. Exchange rate policy is clearly not an end in itself but, as shown by the connections depicted above, has an important role to play in achieving these deeper policy reforms and also the ultimate objectives in terms of growth and welfare.

\section{A Broader Context for Currency Reforms}

For an emerging market economy, keeping domestic inflation low and stable, and controlling inflation expectations, is always a difficult challenge. For all its flaws, the exchange rate link to the U.S. has served as a useful anchor for inflation expectations in China. So what could serve as a suitable alternative anchor for inflation expectations in place of a tightly managed exchange rate?

Marvin Goodfriend and I have argued that China should adopt an explicit inflation objective-a long-run range for the inflation rate and an explicit acknowledgement that low inflation is the priority for monetary policy - as a new anchor for monetary policy (Goodfriend and Prasad, 2007). An inflation objective, coupled with exchange rate flexibility, would work best to stabilize domestic demand in response to internal and external macroeconomic shocks. Indeed, focusing on inflation stability is the best way for monetary policy to achieve broader objectives such as financial stability and high employment growth. Over time, the inflation objective would provide a basis for currency flexibility. Thus, exchange rate reform will be seen as a key component of an overall reform strategy that is in China's short- and long-term interests.

\footnotetext{
${ }^{14}$ See Kose, Prasad, Rogoff and Wei (2006).

${ }^{15}$ See Eichengreen (2004), Prasad, Rumbaugh, and Wang (2005), and Yu (2007).
} 
The time is right for making the switch-economic growth is strong and headline inflation is low. At an operational level, the PBC could continue its current approach to monetary policy, which includes setting targets for money and credit growth. The crucial difference would be to switch the strategic focus from the exchange rate to the inflation objective, which means that the currency could appreciate or depreciate in response to more fundamental economic forces such as productivity growth. This framework would subsume monitoring of monetary aggregates such as M2 and private credit, but directly targeting these aggregates is increasingly inappropriate for an economy that is undergoing rapid structural transformation and changes in the structure of its financial markets.

But how could such a regime- - which is in many ways similar to that advocated for the U.S. by Federal Reserve Board Chairman Ben Bernanke-work effectively in an economy with a weak financial system? The basic condition is that banks' balance sheets must be robust to interest rate fluctuations. The PBC has already made good progress on this front by clearing bad loans from the books of the key large banks and recapitalizing them. Full modernization of the banking system is a long way off, of course. But it would be inadvisable to wait for that outcome before moving to a new monetary framework. Indeed, as noted earlier, effective monetary policy is necessary for pushing forward with financial sector reforms.

I am not advocating a full-fledged inflation targeting regime, although this could serve as a useful long-term goal. The approach I have outlined above is more practical for the foreseeable future, and it should deliver most of the benefits of formal inflation targeting.

Two related points are worth noting. Independent interest rate policy requires a flexible exchange rate, not a one-off revaluation or a sequence of revaluations. A flexible exchange rate buffers some of the effects of interest rate changes, especially in terms of offsetting the temptation for capital to flow in or out in response to such changes. A oneoff revaluation can solve this problem temporarily, but could create even more problems subsequently if interest rate actions in a different direction become necessary, or if investor sentiment and the pressures for capital inflows or outflows shift. This is why the focus on a large one-time revaluation to atone for past sins doesn't get us anywhere, either in terms of the policy debate or in terms of effecting reforms that really matter.

Another crucial point is that exchange rate flexibility should not be confused with full opening of the capital account. An open capital account would allow the currency to float freely and be market-determined. But the exchange rate can be made flexible and the objective of monetary policy independence achieved even if the capital account is not fully open. Indeed, as noted above, there are good reasons why it is preferable to move more gradually on capital account opening than on exchange rate flexibility. A free float with an open capital account is a useful long-term objective, but is not a high priority in the short run.

A concern often expressed by Chinese policymakers is that, given the fragility of the domestic banking system, exchange rate flexibility could be disastrous. There are two 
possible factors behind this concern. One is that sharp changes in the value of the currency could destroy bank balance sheets. There is little evidence, however, that Chinese banks have large exposures to foreign currency assets (and/or external liabilities denominated in renminbi) that would hurt their balance sheets greatly if the renminbi were to appreciate in the short run.

A more serious concern is that outflows of capital could starve the domestic banking system of liquidity by allowing domestic savers to take their money abroad. This is where the difference between exchange rate flexibility and capital account liberalization becomes especially important. There is no reason why, with even the moderately effective capital controls that are in place now, China could not allow for more exchange rate flexibility. A flexible exchange rate, even if it does not yield a "true" market equilibrium rate because capital flows are constrained, can allow for an independent monetary policy. And this flexibility does not by itself generate channels for evading controls on capital flows.

In short, as a reason for not moving more quickly towards a flexible exchange rate, banking system weaknesses constitute a red herring.

\section{Bumps and Lumps Along the Road}

While one may quibble about the pace of reforms and their sequencing, there is undeniably progress being made in terms of various reforms and a recognition on the part of Chinese policymakers about what needs to be done. What could derail this process? I now review a series of risks that the Chinese economy faces, how the present economic circumstances may allow them to be dealt with, and what could be done to mitigate them. This is not meant to be an exhaustive set of risks and one must also emphasize the proviso that, to paraphrase Donald Rumsfeld, the known unknowns may be far less consequential than the risks that we may not even be able to conceive of in advance.

With China's increasing integration into the world economy through its trade and financial linkages, its exposure to external shocks has increased and so has their potential impact on the Chinese economy. It is difficult to compartmentalize risks as emanating from domestic or external sources, however, since it is the interaction of foreign and domestic circumstances that matters for the economic impact of these shocks. With this caveat in mind, let us begin by tracing through some specific shocks that have mattered in previous emerging market crises and see what relevance they may have for China.

1. Sudden stop or reversal of capital inflows. This phenomenon has been associated with a large number of emerging market crises and can be particularly brutal when an economy is heavily dependent on foreign capital. In China's case, this dependence is quite limited. Most of the flow of capital through official channels has been in the form of foreign direct investment (FDI). This form of foreign inflows tends to be the most stable and difficult to reverse in short periods. Furthermore, the amount of annual gross FDI inflows that China received in 2005-6 was about $\$ 80$ billion, which amounts to only 3 percent of GDP. The level of external debt remains low at about 12 percent of GDP 
and, notwithstanding the rising share of short-term debt in total debt, is hardly at a level that is a cause for concern. China's international investment position (Table 5) shows that FDI liabilities account for more than half of total foreign liabilities, and foreign exchange reserves amount to more than double the remaining liabilities (portfolio equity, portfolio debt, and other investment, which includes trade credit, bank loans etc.)

Putting these factors together, a sudden stop of capital inflows must be regarded as a lowprobability event and, in any case, will have little direct short-term impact on the Chinese economy. ${ }^{16}$ By extension, financial crises in other emerging market economies are unlikely to spill over to China, so "contagion" is not a major concern.

2. Plunge in the value of the U.S. dollar against major international currencies. This is an ever-present possibility given the high level of the U.S. current account deficit. Unless the value of the renminbi was in fact to be set against a basket of currencies with a sufficiently high weight on non-U.S. currencies, this would lead to a depreciation of the renminbi in real effective terms, further boosting the competitiveness of Chinese exports in non-U.S. markets. The direct impact on China would be limited (depending also on what happened to U.S. import demand), but the effective depreciation of the renminbi could drive the current account surplus higher, bring in more inflows, and make domestic macroeconomic management even harder. There could of course be major second-round effects if the dollar depreciation led to a spike in U.S. inflation, which in turn led to a tightening by the Fed and a slowdown in U.S. activity, affecting global demand.

3. Collapse of external demand. In the U.S., the "recession" word has been uttered by no less a personality than Greenspan. Of course, he and others do not see this as a likely event, but there are factors like a meltdown of the subprime mortgage market that could ripple through financial markets and trigger a slowdown in domestic consumption. A slowdown in the U.S. economy would have significant spillover effects onto other economies that also constitute major Chinese export markets. Chinese exports of goods and services amount to about 40 percent of GDP and exports to the U.S. account for about one-third of the total. Thus, this is an important risk for the Chinese economy, especially given that net exports have made a sizable contribution to growth in 2005-06.

4. U.S. trade sanctions. About a third of China's exports go to the U.S., so substantial tariffs or quantity restrictions on U.S. imports of Chinese products would certainly hurt export growth. There is a distinct probability that bipartisan legislation will soon be brought to the floor of Congress but, in the interests of making such legislation WTO-compliant and veto proof, it is likely to be less drastic than last year's SchumerGraham bill (which called for across-the-board tariffs of 27.5 percent on imports from China). It is also likely to give the Chinese more time to modify their currency regime by calling for better guidelines to measure currency misalignment and deal with excessive misalignment through the intervention of international organizations such as the IMF. ${ }^{17}$

\footnotetext{
${ }^{16}$ In Goldstein’s (2005) cross-country analysis of external vulnerabilities among emerging market economies, China comes out looking rather good on most dimensions.

${ }^{17}$ The Senate Finance Committee has already proposed some legislation along these lines. The legislation--sponsored by Senators Baucus, Grassley, Schumer and Graham--appears to have
} 
In short, this is a serious risk, but one that ought to come with due warning and time to respond. If the response were to take the form of retaliatory trade sanctions by the Chinese (as was witnessed recently in the spat over the safety of food imports), things could turn ugly very quickly and have detrimental effects on China-U.S. bilateral trade and economic relations.

5. Loss of confidence in the banking system. This is potentially one of the more serious risks in the economy. Deposits in the state-owned banking system are implicitly insured by the government, but this covenant could come into question very quickly. What could trigger this? A new formal deposit insurance system is in fact being put in place, but it is difficult to predict the authorities' reaction if a bank was indeed close to failing and the subsequent reactions of depositors in the entire banking system if the system did work the way it should (i.e., occasionally allowing weak banks to fail). Moreover, although the NPL problem seems to be under control, an economic downturn could lead to a surge in new NPLs because of the credit boom and the consequent rapid expansion of fixed asset investment that is now fueling growth.

The true extent of NPLs in the banking system is unclear. So it is difficult to say conclusively whether the existing stock of foreign exchange reserves will be enough to protect the banking system, but this is likely to be the case even if new NPLs surge and private agents pull a substantial portion of their savings out of bank deposits. Moreover, so long as the capital account remains relatively closed, the possibility of massive capital flight is limited. But the government has recently been opening channels for money to flow out of the economy in order to relieve pressure on the exchange rate. They have encouraged institutional investors to move funds abroad and also relaxed the restrictions on the amount of financial capital that can be taken out of the country by households. History shows that, once these taps are opened, it is very difficult to shut them off.

This poses a significant risk because deposits in the banking system now stand at about 160 percent of GDP while foreign exchange reserves amount to less than 50 percent of GDP. The risk of such a massive flight out of bank deposits is small. But let's consider a more plausible scenario. What if depositors (both households and enterprises) became concerned enough to move, say, ten percent of their deposits out of the banking system into foreign assets? Given the size of total bank deposits, there could be significant financial market turbulence associated with such a large absolute amount of capital flowing out of the country in a relatively short period of time.

One can envision such turbulence having a cascading effect on the economy. It could lead banks to become more cautious in their lending, generate more NPLs as marginally viable firms find it higher to get working capital, force the regulator to come down harder on bank lending, and cut overall credit and investment growth. Private sector enterprises, especially small and medium-sized ones, would be particularly hard-hit by such a credit squeeze. These developments could also make households increase precautionary saving

broad bipartisan support and could be brought to a floor vote sometime this fall. Similar legislation has been proposed by the Senate Banking Committee (Dodd-Shelby et al.) and the House of Representatives (a revised version of last year's Ryan-Hunter bill). 
and rein in spending, thereby setting off a deflationary spiral. Once again, the absence of flexible policy tools such as independent interest rate policy could lead to more heavyhanded intervention, which could make things worse in the short run.

While the possible magnitude and implications of a surge in capital outflows and their consequences are open to debate, these numbers do serve to drive home one important point. Rather than focus on capital account liberalization, which can be risky if circumstances change and there is pressure for outflows, it would be far better to deal with the root problem - the lack of exchange rate flexibility and the absence of an independent monetary policy.

6. Asset price busts. In the absence of a well-developed financial system and other viable alternatives to bank deposits that now have negative real rates of return, Chinese investors have been pouring money into the stock market. Both household and enterprise savings have been flowing in fast and strong into equities; growth in household bank deposits has in fact turned negative in recent months as investors have gotten swept up in the stock market euphoria and the real returns on bank deposits have fallen further into negative territory. Are stock market valuations completely out of whack and susceptible to a steep fall? It is difficult to answer this question based on traditional metrics such as price-earnings ratios. Many listed companies in China-most of which are still large state-owned or joint venture companies-are getting subsidized inputs, as noted earlier, so their putative earnings must be treated with caution. At any rate, with the surge in stock prices over the last year, the average price-earnings ratio on the Shanghai A-shares market more than tripled from 17 at end-2005 to 53 percent in April 2007, although it has since descended a smidgen towards terra firma--to about 44 in July 2007 (Figure 15).

The massive run-up in equity prices within a very short period of time, and the increasingly wide participation in the stock market by uninformed investors, make it likely that the market is vulnerable to sharp swings in prices. ${ }^{18}$ Despite the recent equity market reforms that removed the overhang of nontraded shares, about two-thirds of shares are still held by institutional investors (mostly state-owned) and are not actively traded. This implies that individual investors' aggregate stock market wealth amounts to at most 30 percent of GDP, but a sharp fall in equity prices could still spook retail investors and generate broader concerns about the domestic financial system. While such a shock could in itself be contained by the authorities, the sort of cascading effects discussed in the previous point could again become relevant.

\footnotetext{
${ }^{18}$ Press reports indicate that, in recent weeks, new individual accounts in the A-share market are being opened at the rate of about 100,000 a day. The total number of accounts on both the Shanghai and Shenzhen stock markets--including A-share, B-share and managed fund accounts-is now estimated to be about 108 million. A recent article in the newspaper China Daily describes how some firms are looking for ways to reduce disruptions to workflow and the distractions caused by employees trying to surreptitiously conduct stock trades while at work. One firm has reportedly set aside half an hour in the morning and half an hour in the afternoon of each workday when employees are permitted to devote their full attention to stock trading on the internet!
} 
7. Social instability. This is another wildcard. The rising inequality of incomesbetween rural and urban areas, between well-educated and low-skilled workers, etc.-—has created deep resentment in a society that is ostensibly driven by egalitarian ideals. ${ }^{19}$ Moreover, the effects of institutional weaknesses such as corruption and lack of public sector transparency are felt more keenly by the poor. Such tensions could very easily boil over for any number of relatively minor reasons. The Chinese Communist Party has hitherto managed to keep a lid on social instability by quickly isolating and beating back such incidents, but these could easily spin out of control if the government responds to some external shock in a way that causes the burden to fall largely on the poor.

8. A grab bag of other issues. There are other risks as well that could slow growth. A sharp increase in oil prices could affect Chinese industrial output. However, China has made some progress in building up its stockpile of oil reserves and there is room in the budget for short-term increases in subsidies, so this is unlikely to affect growth much. Demographic pressures are also building and, as dependency ratios rise and the share of the working-age population declines, these pressures could have adverse implications for labor supply and also for social expenditures on health. The model of growth led by capital- and energy-intensive industrial production has led to severe environmental degradation that is becoming rather obvious and has major welfare consequences. A number of other risks are even harder to quantify. On the political side, a flare-up in tensions across the Taiwan straits would have unpredictable consequences if there was a rapid escalation of conflict. Environmental accidents (a couple of which have been witnessed recently) could serve as a trigger for much broader social unrest, especially since the burden of such events falls disproportionately on the poor.

The main message of this section is that the traditional risks faced by emerging market economies, especially those related to an open capital account, do not loom large in the case of China. There are, however, other less prominent factors that could easily trigger unfavorable economic dynamics that, even if they don't rise to the level of a crisis, could have serious adverse repercussions on growth and welfare. And the potency and flexibility of macroeconomic tools to deal with such developments is constrained by the panoply of policies that has supported growth so far.

\section{Nudging Reforms Along}

China has achieved remarkable economic progress in the last three decades. But a great deal of work remains to be done to make the economy resilient to large shocks, to ensure the sustainability of its growth, and to translate this growth into corresponding improvements in the economic welfare of its citizens. One important lesson from the experiences of other countries is that periods of high growth can sometimes mask deep underlying problems. At the same time, favorable domestic and external circumstances may provide an excellent—but possibly narrow—window of opportunity for tackling deep-rooted problems without much economic disruption.

19 As of December 2006, rural household per capita income was 31 percent of urban household per capita income, down from 35 percent in 2003. Over the last three years, average annual per capita income growth was about 7 percent in rural areas, compared to 11.5 percent in urban areas. 
For one, sustained capital inflows and appreciation pressures on the exchange rate may make it easier to manage the move towards greater exchange rate flexibility. Exits from a currency peg when there are massive outflows due to pressures for depreciation tend to be much messier. Similarly, the current state of low inflation provides a good environment to consider setting a long-run low inflation objective as a nominal anchor. And the favorable fiscal position provides some room for rethinking social expenditure priorities, particularly in education and health care.

There is no question that Chinese policymakers face a difficult balancing act - they need to ensure that each set of reforms proceeds at a reasonably rapid pace and, at the same time, that a broad set of reforms move along in tandem. This will involve more of a leap into the unknown and will carry attendant risks, but the risks of not moving at a sufficient pace and along a broad front are even greater. Indeed, perhaps the best way to mitigate the unknowable risks at the current juncture will be, as part of the reform agenda, to develop flexible and potent policy instruments that allow for nimble responses when shocks hit.

External pressure can play a helpful role in this reform process, but only if it is placed in the right context. For instance, the debate in the U.S. about the Chinese exchange rate regime has been distorted in some ways, and made political rather than substantive, by placing it in the narrow context of the U.S.-China trade balance. There is an important strategic (and educational) element related to reframing the exchange rate issue in a broader context. This is where external pressure from the international community can be helpful, not in the form of threats but by reorienting the discussion in a fashion that brings into sharper focus the linkages between currency reform and other core reforms on which there is broad consensus within China.

Furthermore, working with the Chinese to develop deadlines for achieving specific policy goals would be useful if done in a collaborative rather than confrontational manner.

These intermediate steps could serve as concrete guideposts for the reform process and help break down internal resistance to the reforms. Commitments that the Chinese made in the context of accession to the World Trade Organization, for instance, have helped to galvanize internal reforms. In China-as in any other country-there are some groups that stand to lose disproportionately from certain reforms, even if those reforms may be hugely beneficial overall. This is precisely where external pressure, if applied judiciously, can be helpful in generating enough momentum to help the forces that are predisposed towards undertaking reforms. A confrontational approach, on the other hand, could well prove counterproductive by bolstering the forces opposed to reform and allowing them to paint certain reforms as being detrimental to China and in the interests only of other countries.

Ultimately, as far as Chinese reforms are concerned, there is a set of shared interests between policymakers in China, the U.S. and elsewhere. For it is deep and enduring reforms that promote sustained and balanced growth in China that are in the best interests of both China and the world economy. 


\section{References}

Allen, Franklin, Qian, Jun, and Qian, Meijun, 2005, “Law, Finance, and Economic Growth in China,” Journal of Financial Economics, Vol. 77, pp. 57-116.

Aziz, Jahangir, 2006, “Rebalancing China’s Economy: What Does Growth Theory Tell Us?” IMF Working Paper 06/291.

Blanchard, Olivier, and Francesco Giavazzi, 2005, "Rebalancing Growth in China: A Three-Handed Approach,” MIT Department of Economics Working Paper 05/32.

Bosworth, Barry, and Susan Collins, 2007, “Accounting for Growth: Comparing China and India,” NBER Working Paper No. 12943.

Chamon, Marcos, and Eswar Prasad, 2007, “The Determinants of Household Savings in China,” forthcoming IMF Working Paper.

Cheung, Yin-Wong, Menzie Chinn, and Eiji Fujii, 2007, “The Overvaluation of Renminbi Undervaluation,” Journal of International Money and Finance, forthcoming.

Wendy Dobson, and Anil Kashyap, 2006, “The Contradiction in China’s Gradualist Banking Reforms,” Brookings Papers on Economic Activity, Fall, pp. 103-48

Dollar, David, and Aart Kraay, 2006, "Neither a Borrower Nor a Lender: Does China’s Zero Net Foreign Asset Position Make Economic Sense?” Journal of Monetary Economics, Vol. 53, No. 5, pp. 943-71.

Dollar, David, and Shang-Jin Wei, 2007, “Das (Wasted) Kapital: Firm Ownership and Investment Efficiency in China,” IMF Working Paper 07/9.

Dunaway, Steven, and Eswar Prasad, 2004, “Interest Rate Liberalization in China,” Oped article in International Herald Tribune, December 3.

Dunaway, Steven, Lamin Leigh, and Xiangming Li, 2006, "How Robust are Estimates of Equilibrium Real Exchange Rates: The Case of China,” IMF Working Paper 06/220.

Eichengreen, Barry, 2004, “Chinese Currency Controversies,” CEPR Discussion Paper 4375 (London, UK).

Frankel, Jeffrey, 2006, “On the Yuan: The Choice Between Adjustment Under a Fixed Exchange Rate and Adjustment under a Flexible Rate,” CESifo Economic Studies, Vol. 52, No. 2, pp. 246-75. 
Goldstein, Morris, and Nicholas R. Lardy, 2004, "What Kind of Landing for the Chinese Economy?” Policy Brief No. PB04-7, Institute for International Economics (Washington, DC).

Goldstein, Morris, 2005, “Renminbi Controversies,” Manuscript, Peterson Institute for International Economics (Washington, DC).

Goldstein, Morris, 2005, "What Might the Next Emerging-Market Financial Crisis Look Like,” Working Paper 05-7 Institute for International Economics (Washington, DC).

Goodfriend, Marvin, and Eswar Prasad, 2007, “A Framework for Independent Monetary Policy in China,” CESifo Economic Studies, Vol. 53, No. 1, pp. 2-41.

Houser, Trevor and Daniel Rosen, 2007, “China Energy: A Guide for the Perplexed,” Policy Brief, Peterson Institute for International Economics.

IMF, 2006, Staff Report for 2006 Article IV Consultation with China (Washington, DC).

Jeanne, Olivier, 2007, “International Reserves in Emerging Market Countries: Too Much of a Good Thing?” Brookings Papers on Economic Activity, forthcoming.

Kose, M. Ayhan, Eswar Prasad, Kenneth Rogoff and Shang-Jin Wei, 2006, "Financial Globalization: A Reappraisal,” IMF Working Paper 06/189.

Lane, Philip R., and Sergio L. Schmukler, 2006, “The International Financial Integration of China and India,” manuscript, World Bank.

Lardy, Nicholas, 2006, “China: Toward a Consumption-Driven Growth Path,” Policy Brief 06-6, Peterson Institute for International Economics (Washington, DC).

Leigh, Lamin, and Richard Podpiera, 2006, “The Rise of Foreign Investment in China's Banks: Taking Stock,” IMF Working Paper 06/292.

McKinnon Ronald, 2007, "Why China Should Keep its Exchange Rate Pegged to the Dollar: A Historical Perspective from Japan” International Finance, forthcoming.

Perkins, Dwight, and Thomas Rawski, 2007, "Forecasting China's Economic Growth over the Next Two Decades,” manuscript, Harvard University.

Podpiera, Richard, 2006, “Progress in China’s Banking Sector Reform: Has Bank Behavior Changed?” IMF Working Paper 06/71.

Prasad, Eswar (editor), 2004, "China's Growth and Integration into the World Economy" IMF Occasional Paper No. 232. 
Prasad, Eswar, Thomas Rumbaugh, and Qing Wang, 2005, "Putting the Cart Before the Horse? Capital Account Liberalization and Exchange Rate Flexibility in China,” China and the World Economy, Vol. 13, No. 4, pp. 3-20.

Prasad, Eswar, and Raghuram Rajan, 2006, "Modernizing China’s Growth Paradigm,” American Economic Review, Vol. 96, No. 2, pp. 331-36

Prasad, Eswar, and Shang-Jin Wei, 2007, “China’s Approach to Capital Inflows: Patterns and Possible Explanations," in Capital Controls and Capital Flows in Emerging Economies: Policies, Practices and Consequences, ed. by Sebastian Edwards (forthcoming; Chicago IL: University of Chicago Press).

Prasad, Eswar, 2007a, “Exchange Rate Flexibility in China: Why It Really Matters and How to Make Progress,” Testimony at the Senate Finance Committee Hearing on "Risks and Reform: The Role of Currency in the U.S.-China Relationship," March 28. Posted at http://prasad.aem.cornell.edu

Prasad, Eswar, 2007b, "Reform and Liberalization of China's Financial Sector," Testimony at the U.S. House of Representatives Committee on Financial Services Hearing on "U.S. Interests in the Reform of China's Financial Sector," June 6. Posted at http://prasad.aem.cornell.edu

Yu, Yongding, 2007, “Ten Years After the Asian Financial Crisis: The Fragility and Strength of China's Financial System,” manuscript, Chinese Academy of Social Sciences, Beijing. 
Figure 1a. Growth and Inflation

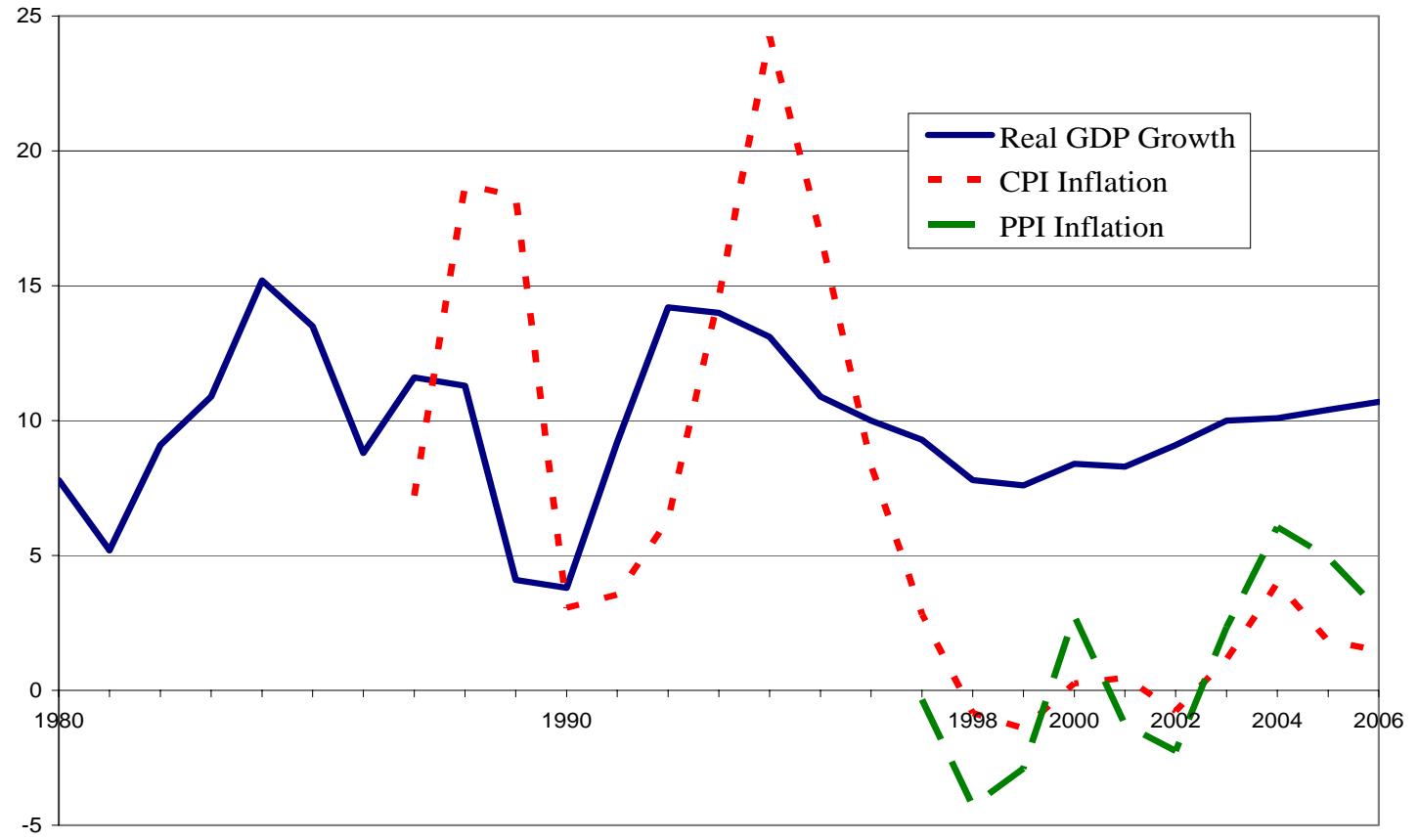

Source: CEIC and IFS

Figure 1b. CPI Inflation (year on year)

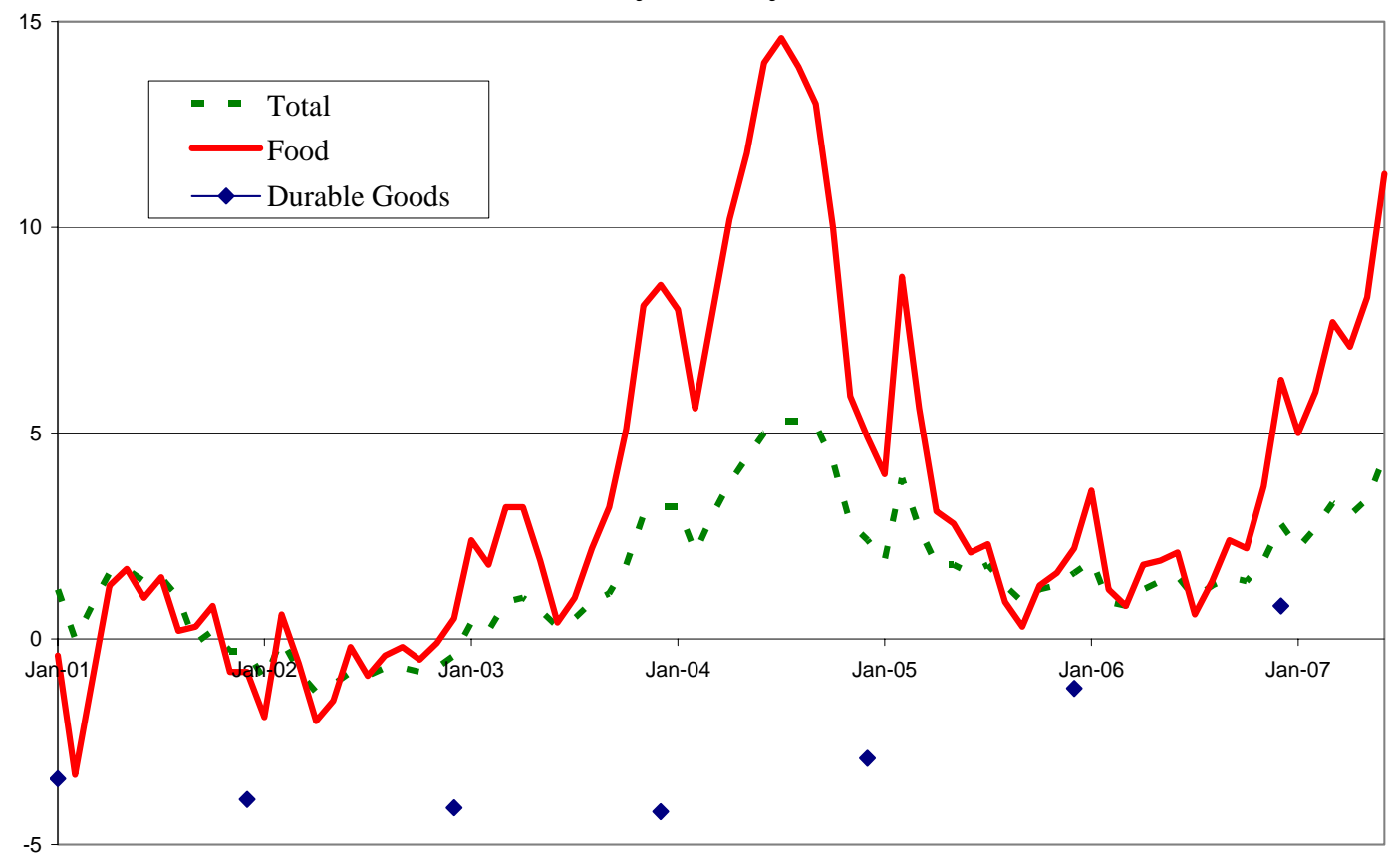

Source: CEIC and author's calculations

Note: Data on durable goods prices available only quarterly. 
Figure 2. Government Deficit and Public Debt

(in percent of GDP)

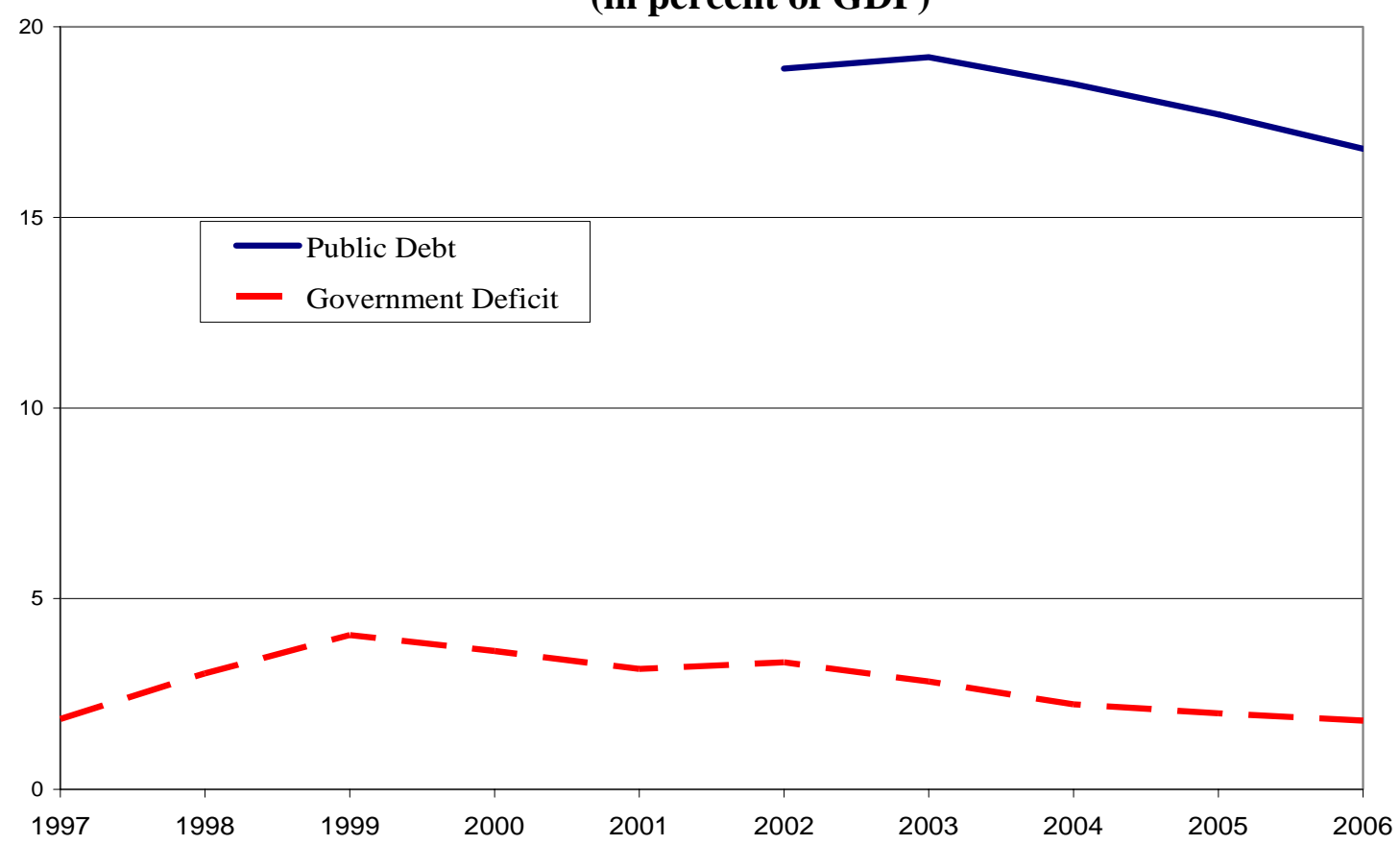

Source: IMF

Figure 3. Contributions of Components to Nominal GDP Growth (expenditure based)

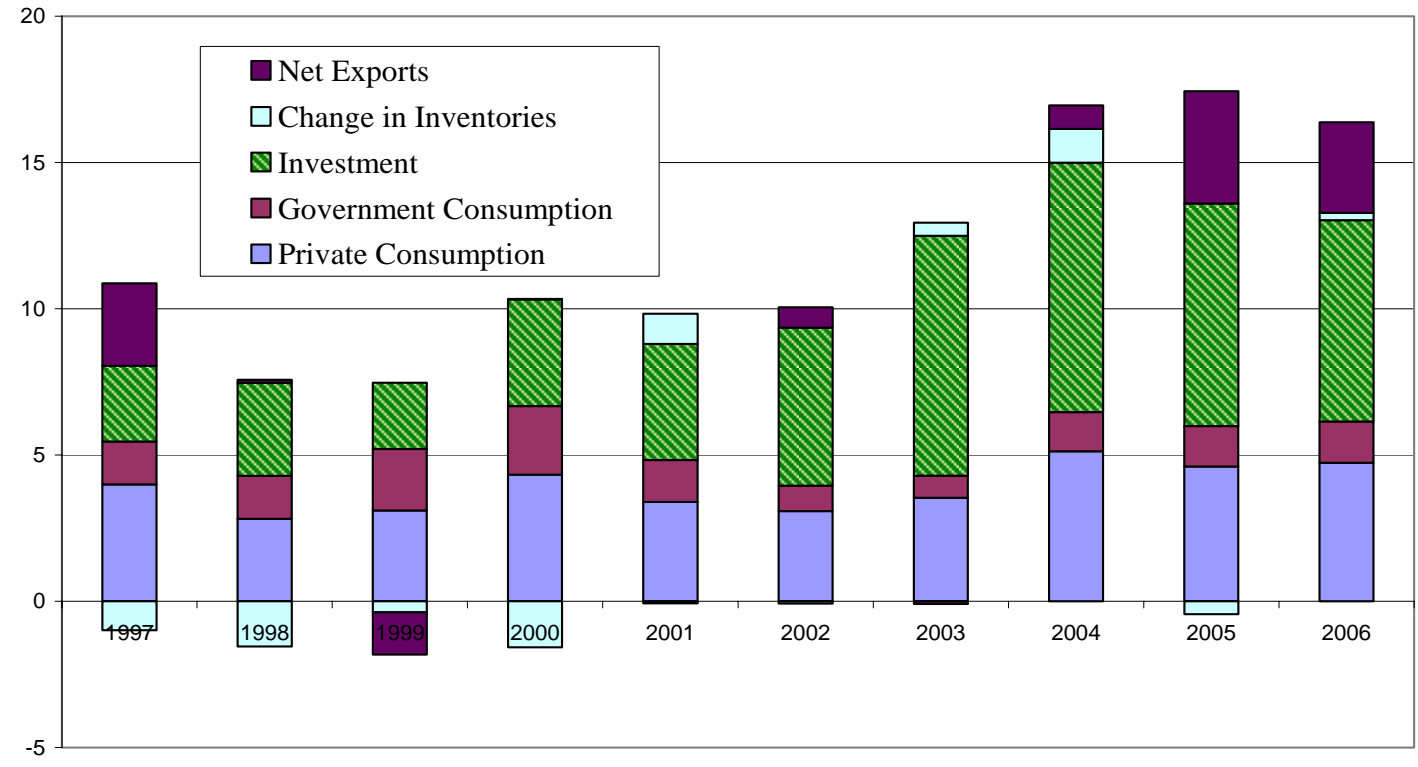

Source: CEIC and author's calculations 
Figure 4. Capital Formation

\section{Nominal Growth}

(annual)

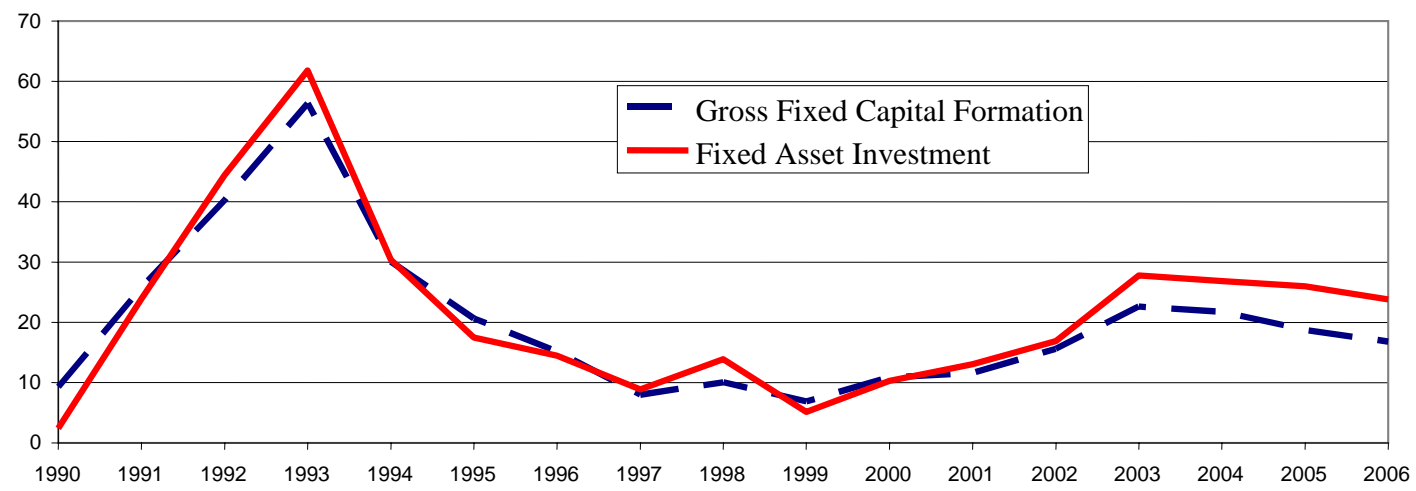

\section{Real Growth}

(annual)

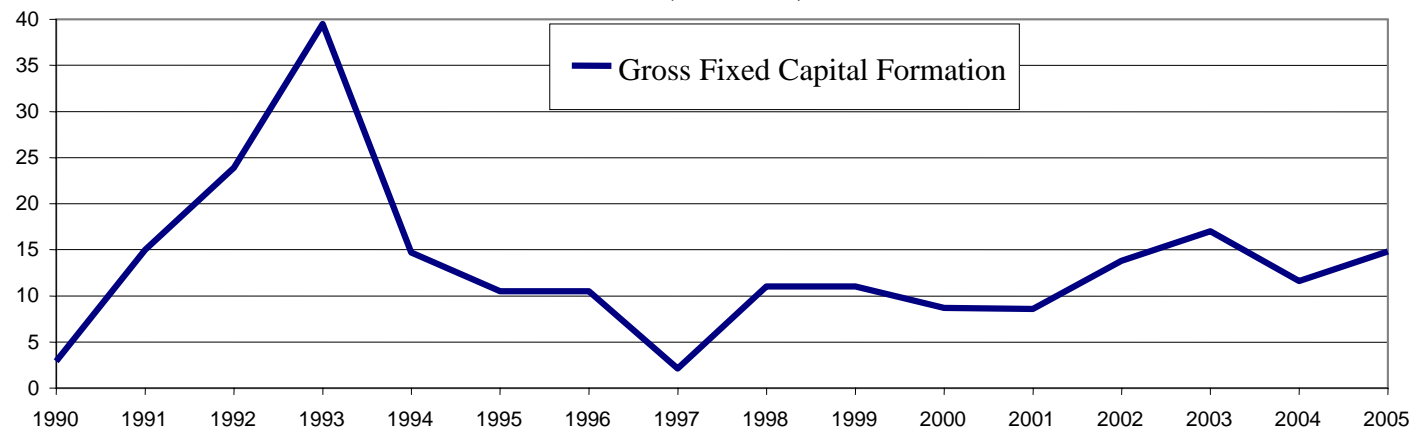

Investment to GDP ratio

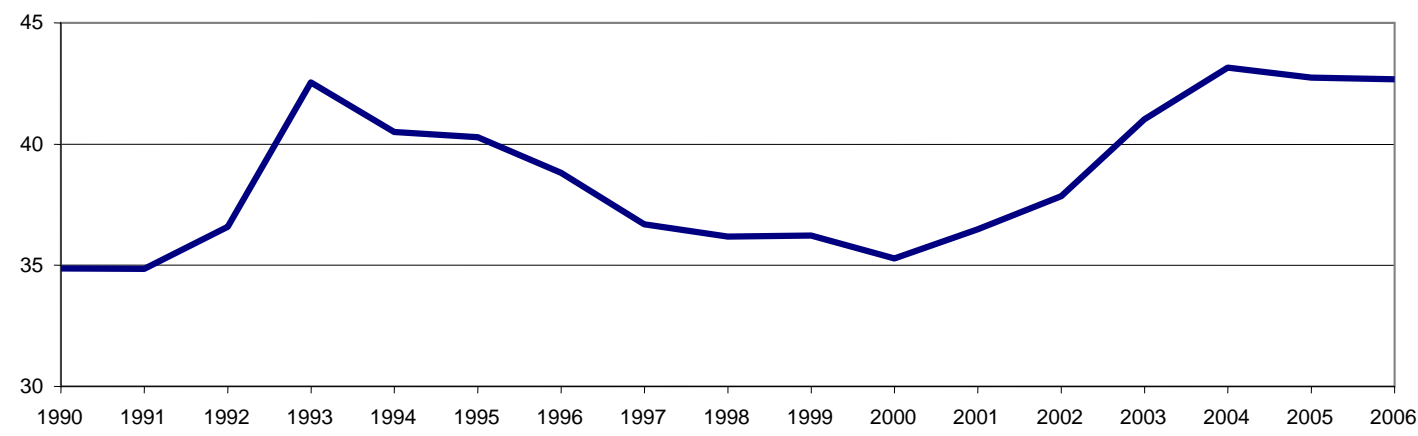

Source: CEIC, WDI and author's calculations

Notes: GFCF is more in line with international concepts. FAI covers only large urban enterprises and includes spending on land. The investment to GDP ratio in the bottom panel is based on gross capital formation, which includes GFCF and inventory accumulation. 
Figure 5a. Base Lending and Deposit Rates

(1-year rates, in percent)

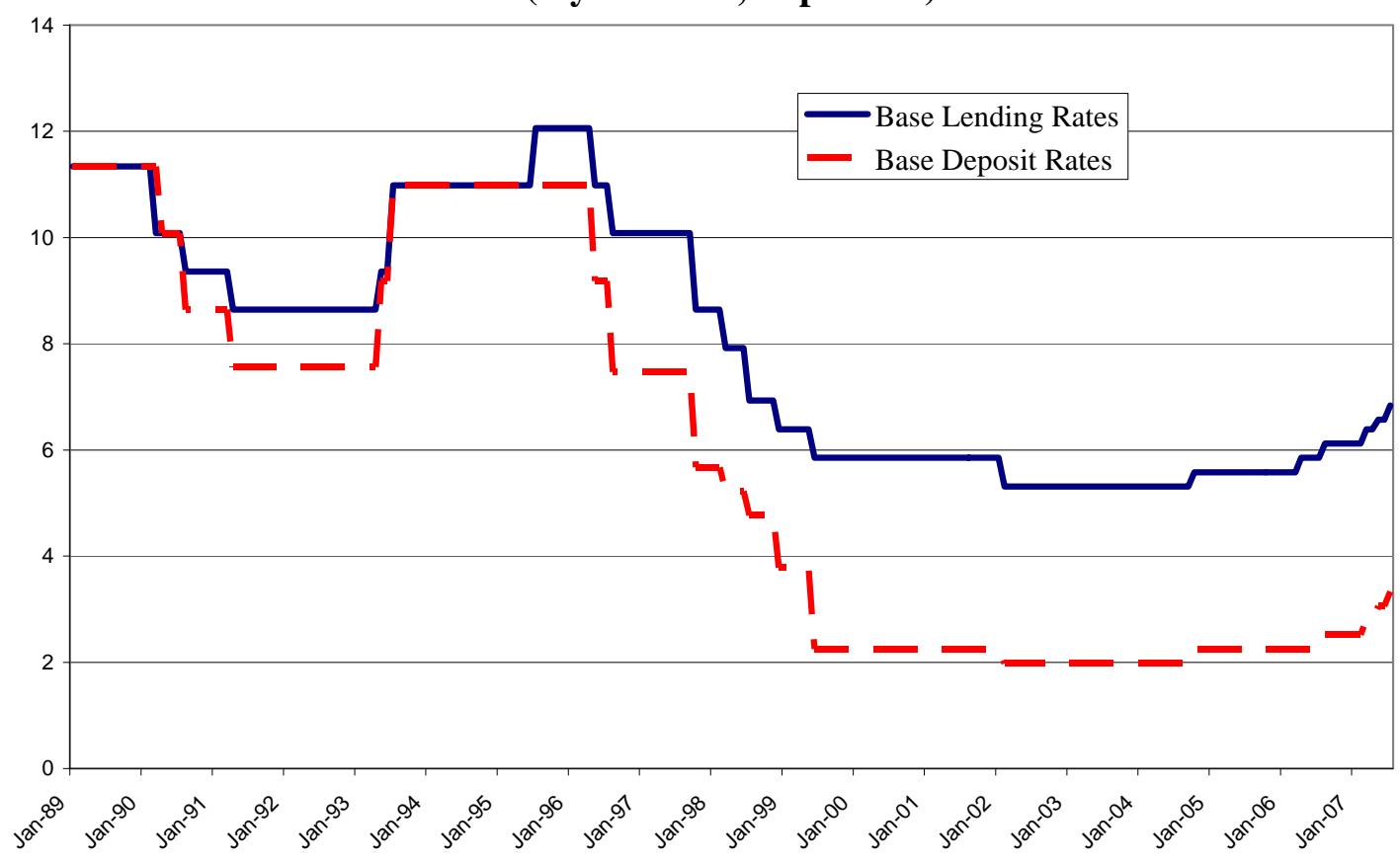

Source: CEIC

Figure 5b. Real Lending and Deposit Rates (1-year rates, in percent)

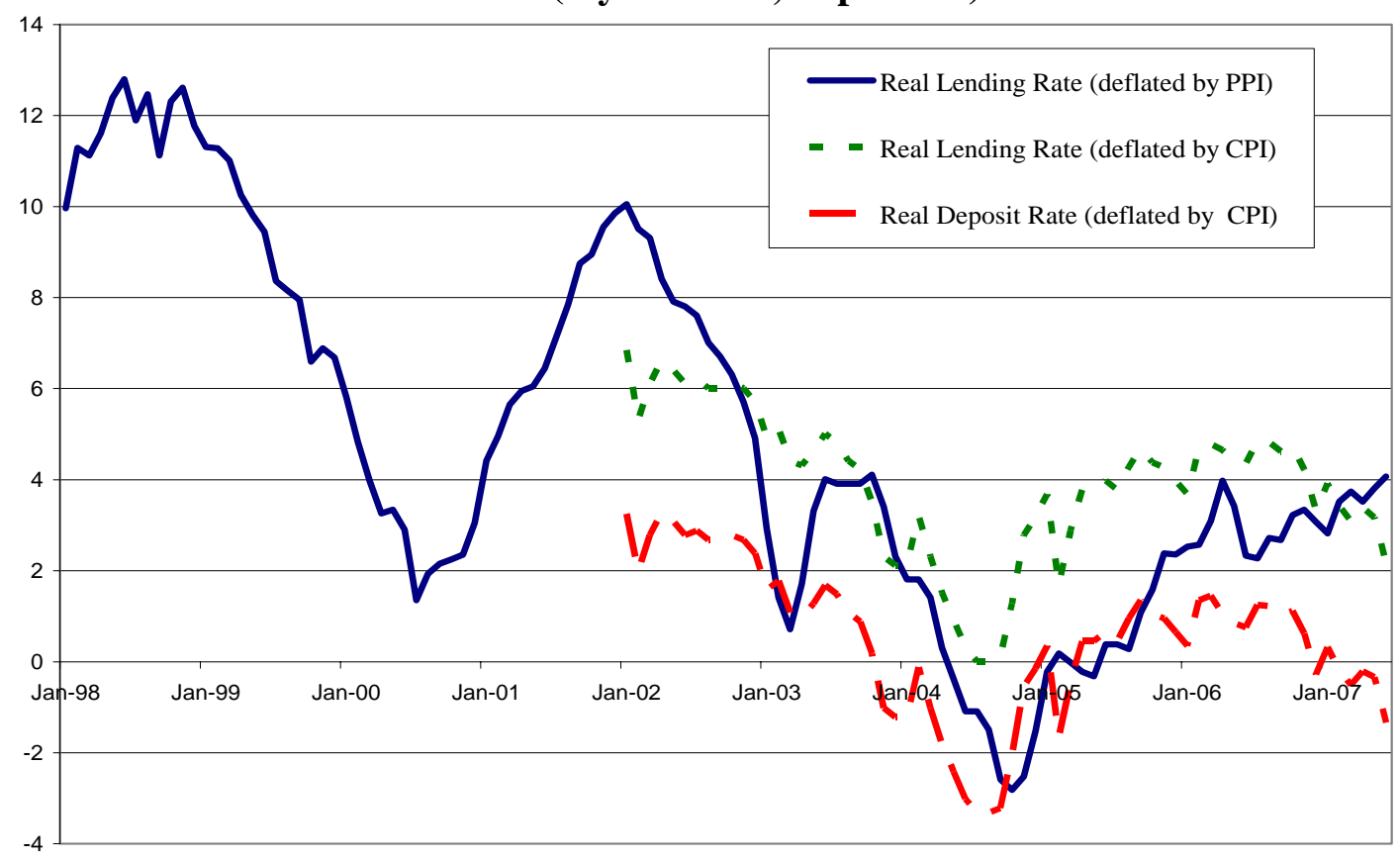

Source: CEIC and author's calculation

Notes: Real rates calculated by deflating the nominal rates by twelve- month trailing CPI or PPI. 
Figure 6. Base and Actual Lending Rates (1-year rates, in percent)

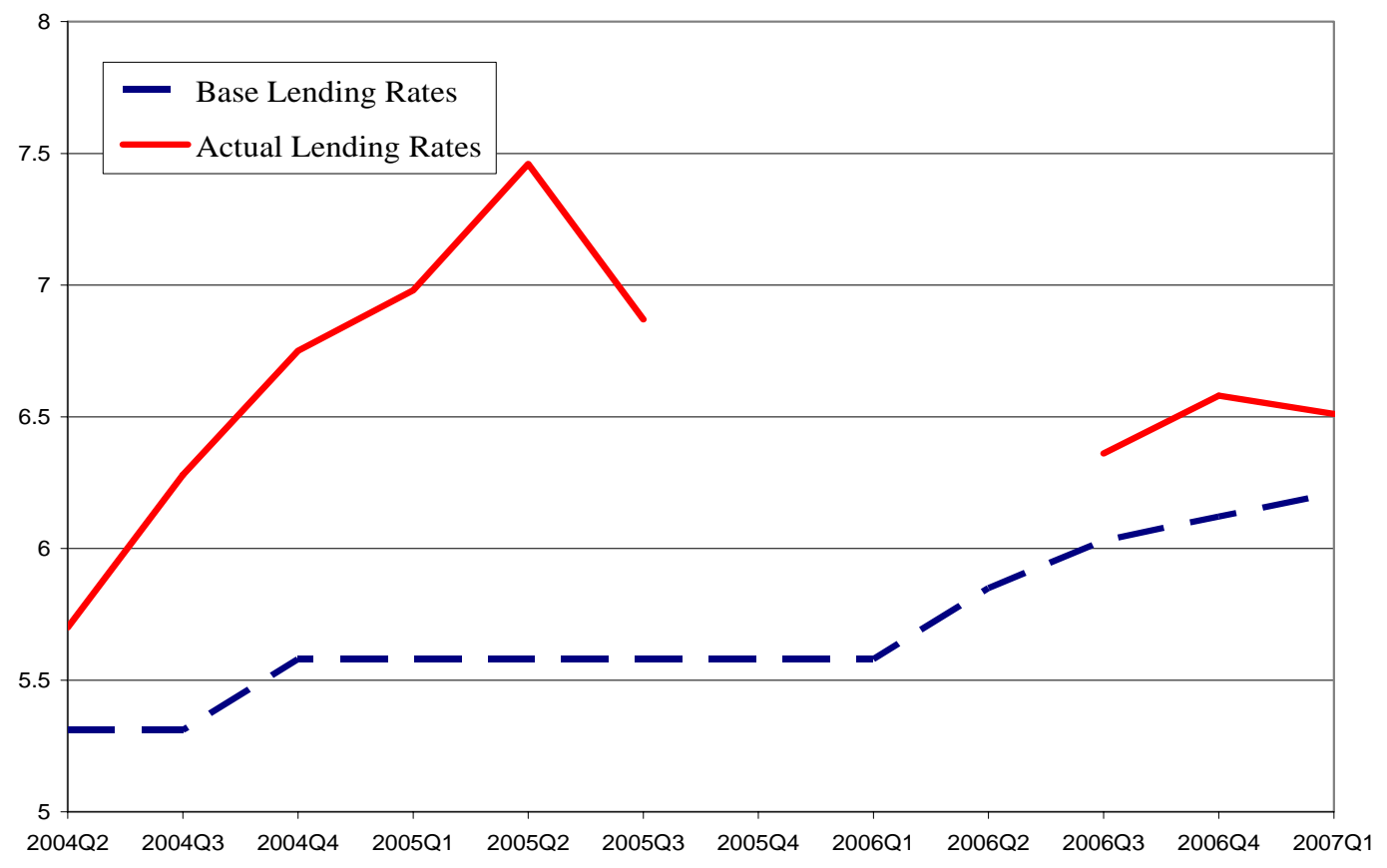

Source: CEIC and PBC Quarterly Monthly Policy Reports

Note: Data not available for 2005Q4-2006Q2 
Figure 7a. Total Deposits in Financial Instiutions

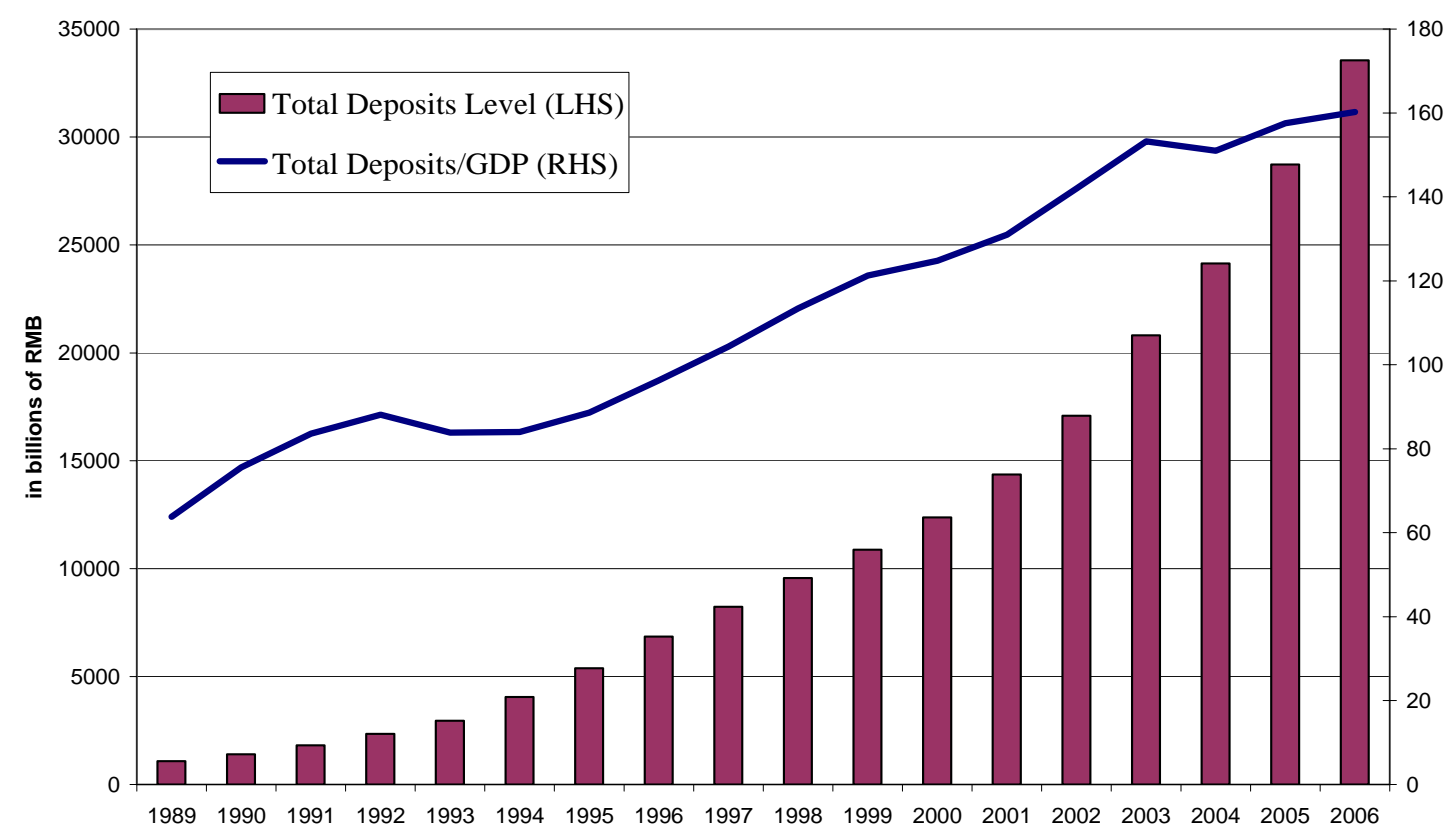

Source: CEIC and author's calculations

Figure 7b. Growth of Deposits and Contributions of Components (in percent)

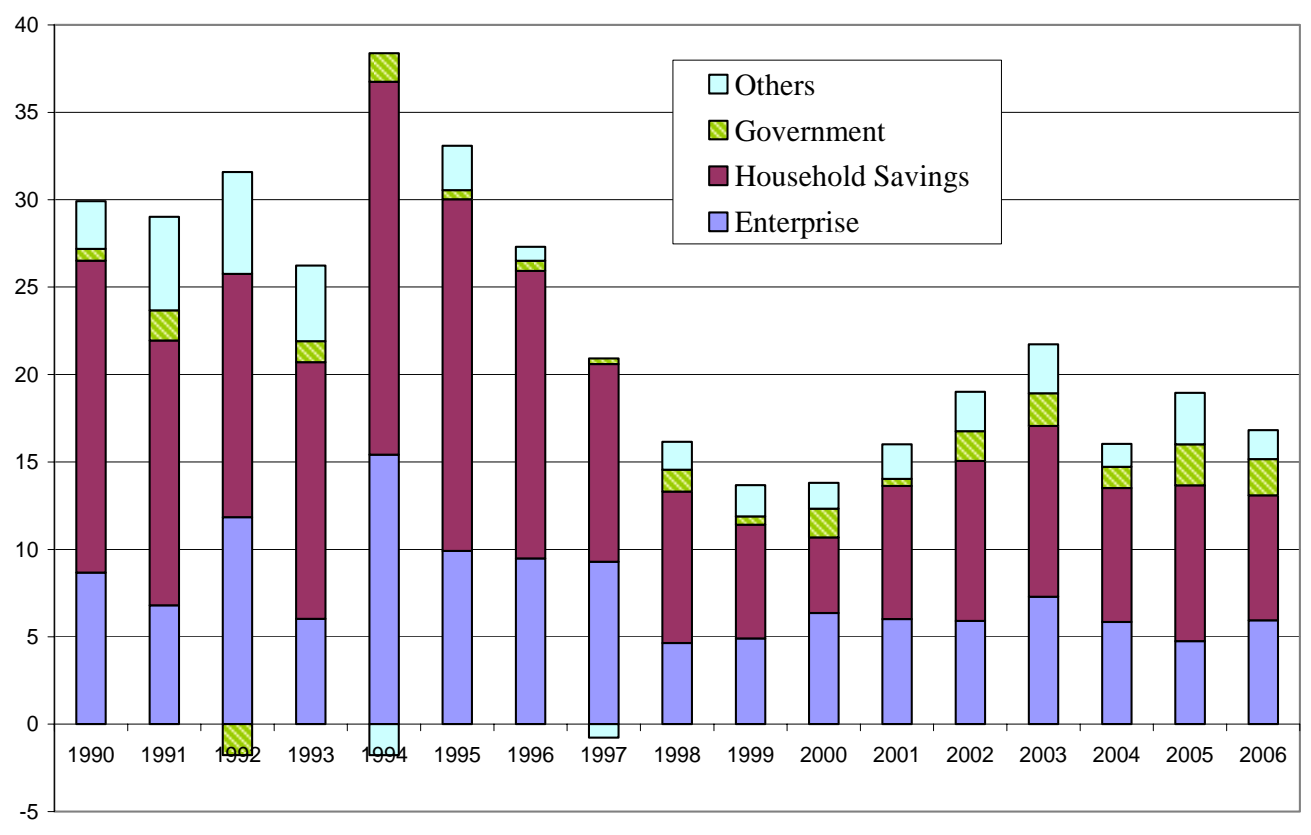

Source: CEIC and author’s calculations 
Figure 8. Current Account/GDP, Export and Import Growth

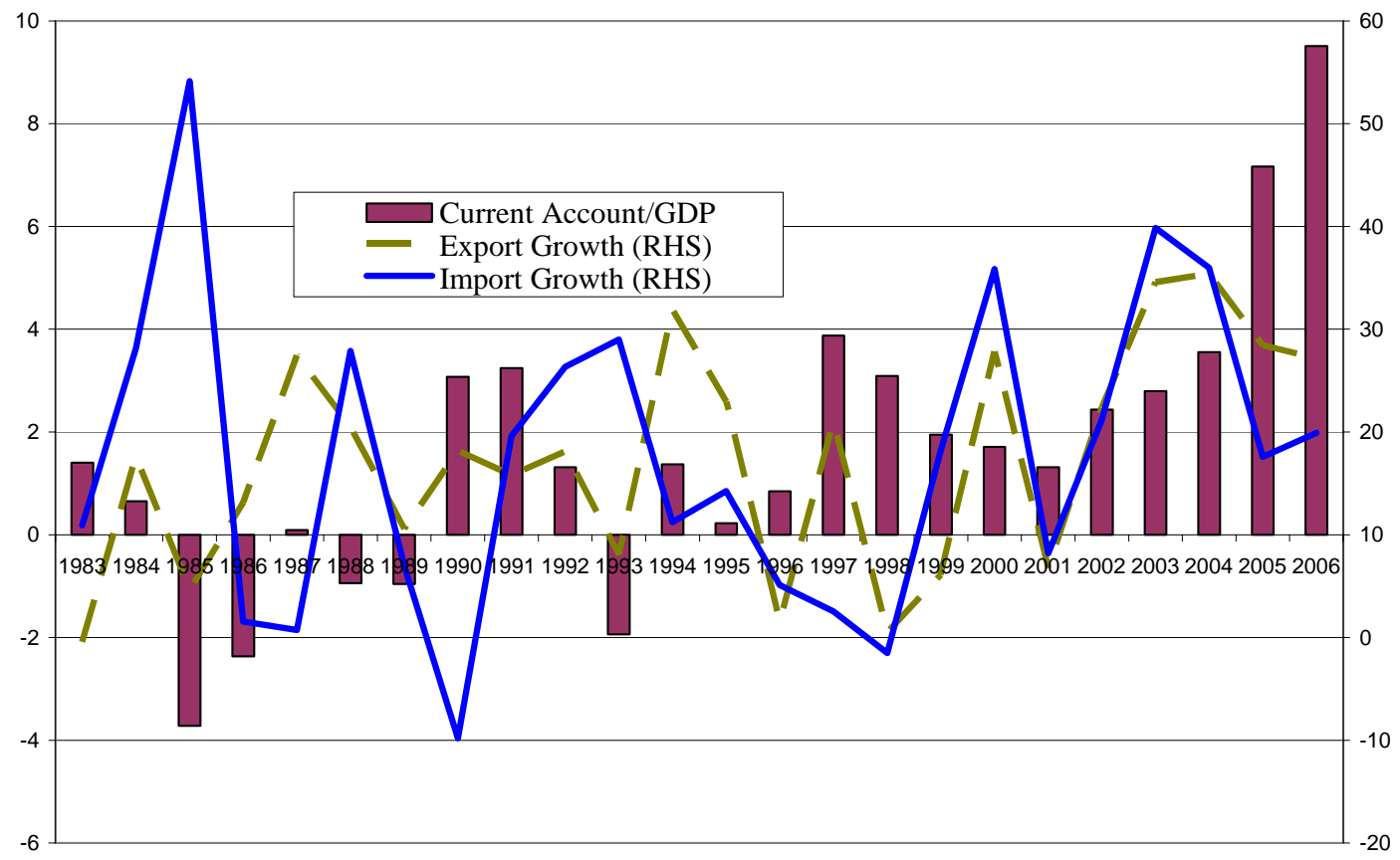

Source: CEIC and author's calculations

Figure 9. Real and Nominal Effective Exchange Rates

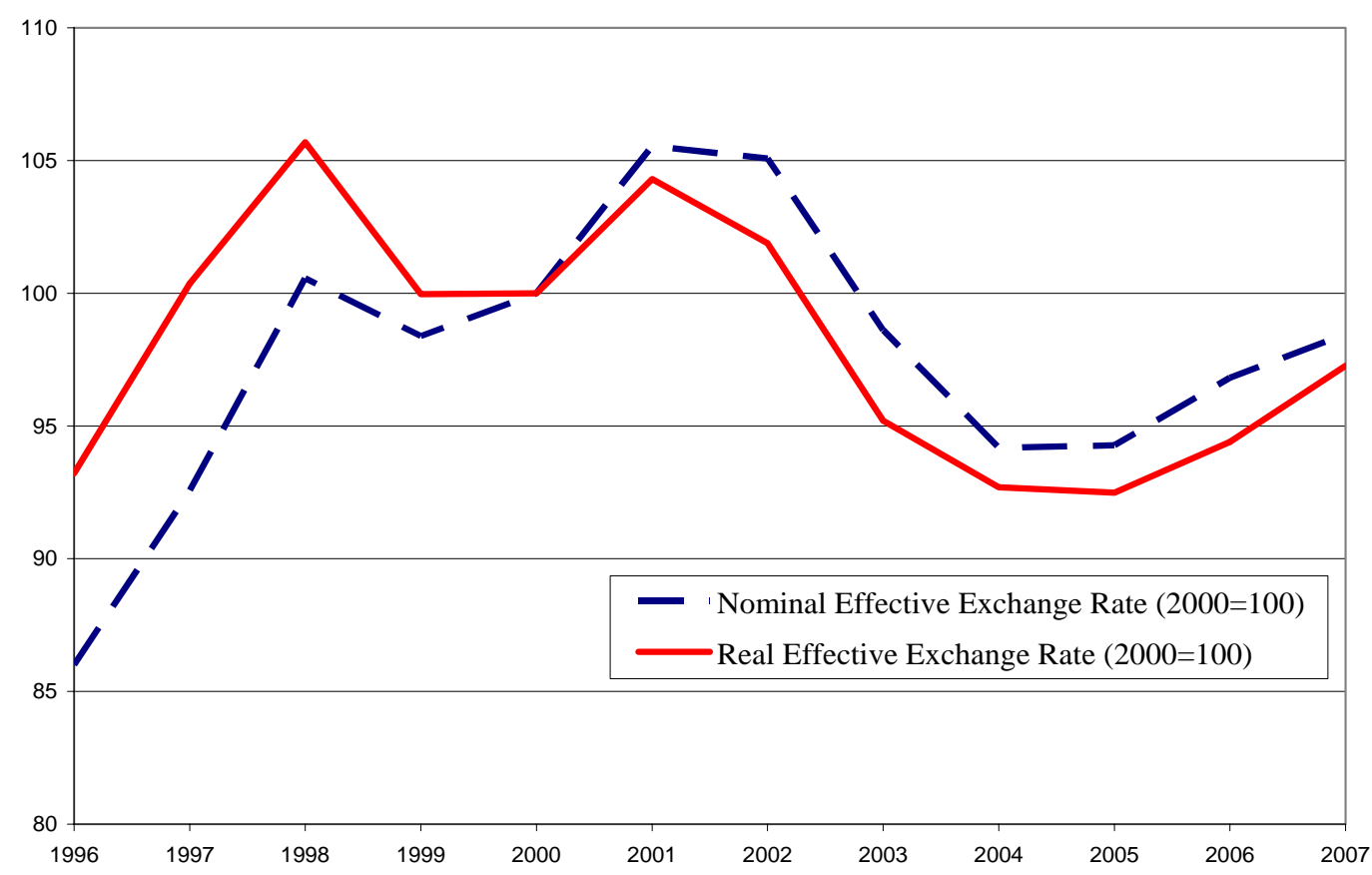

Source: IFS

Note: Data for 2007 are for end-March 
Figure 10. Foreign Exchange Reserves: Flows and Stocks (in billions of USD)

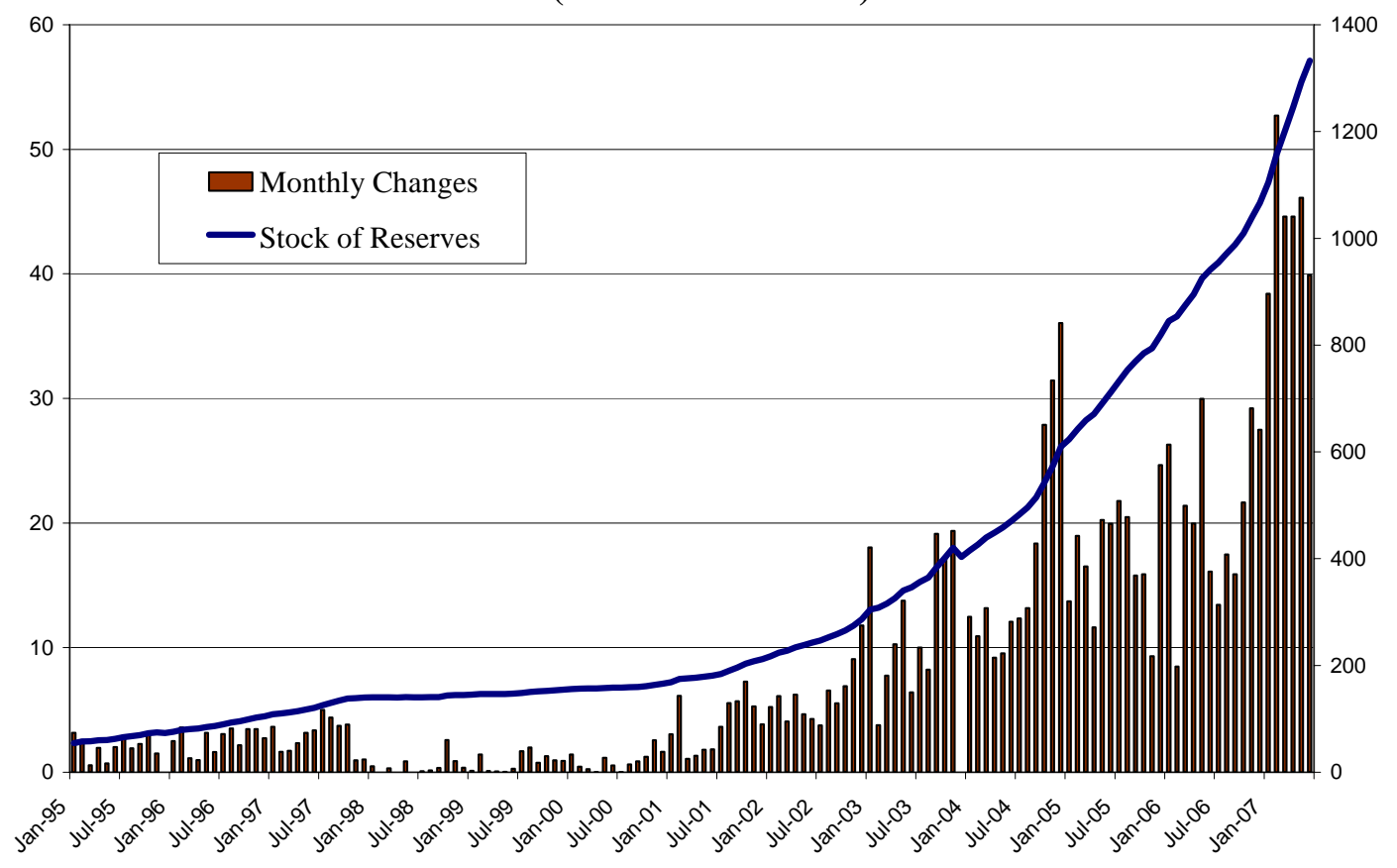

Source: CEIC and author's calculations

Figure 11. Money and Credit Growth (year on year, in percent)

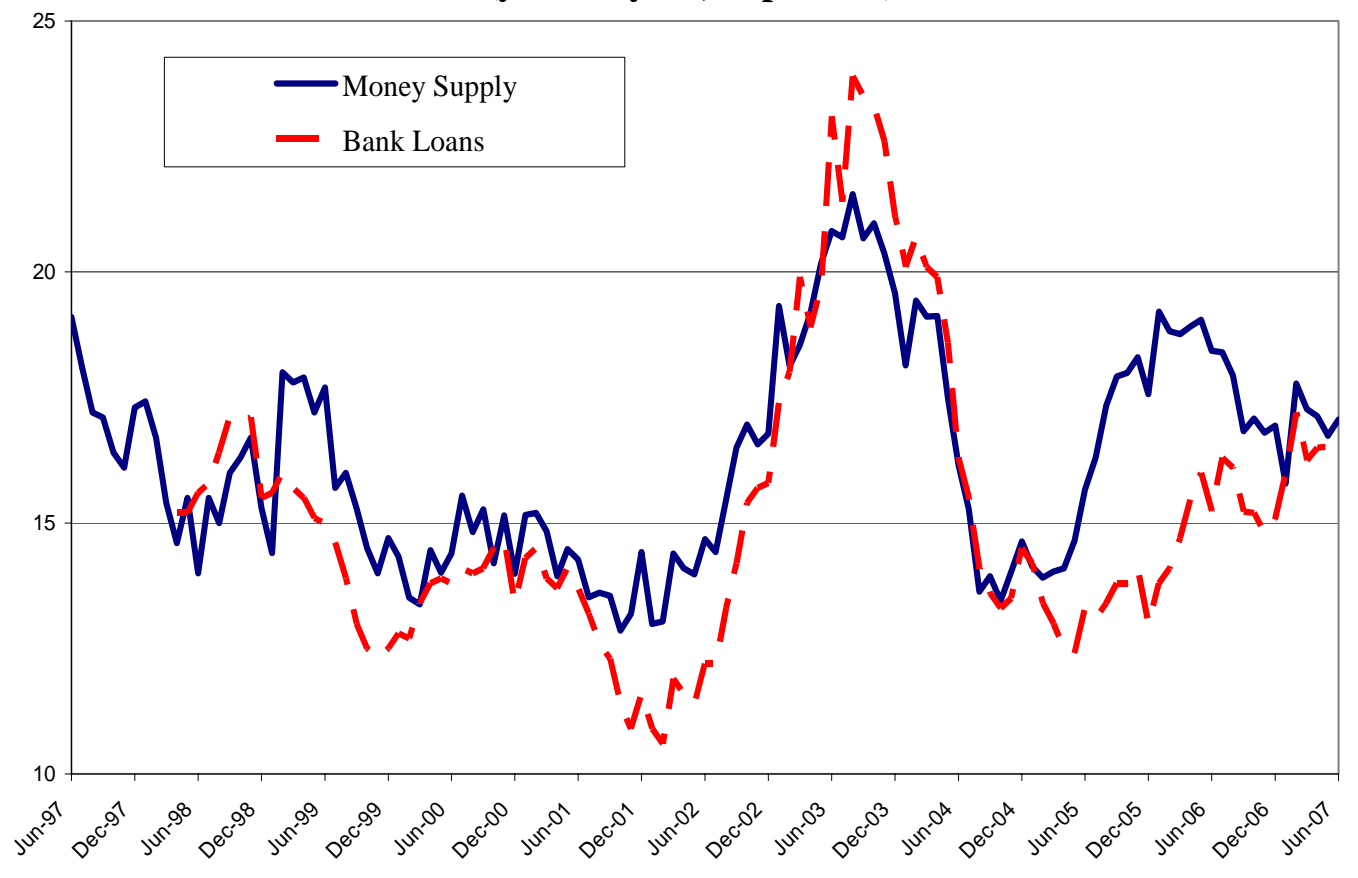

Source: CEIC 
Figure 12a. Required Reserves and Excess Reserves Ratio (in percent of total deposits)

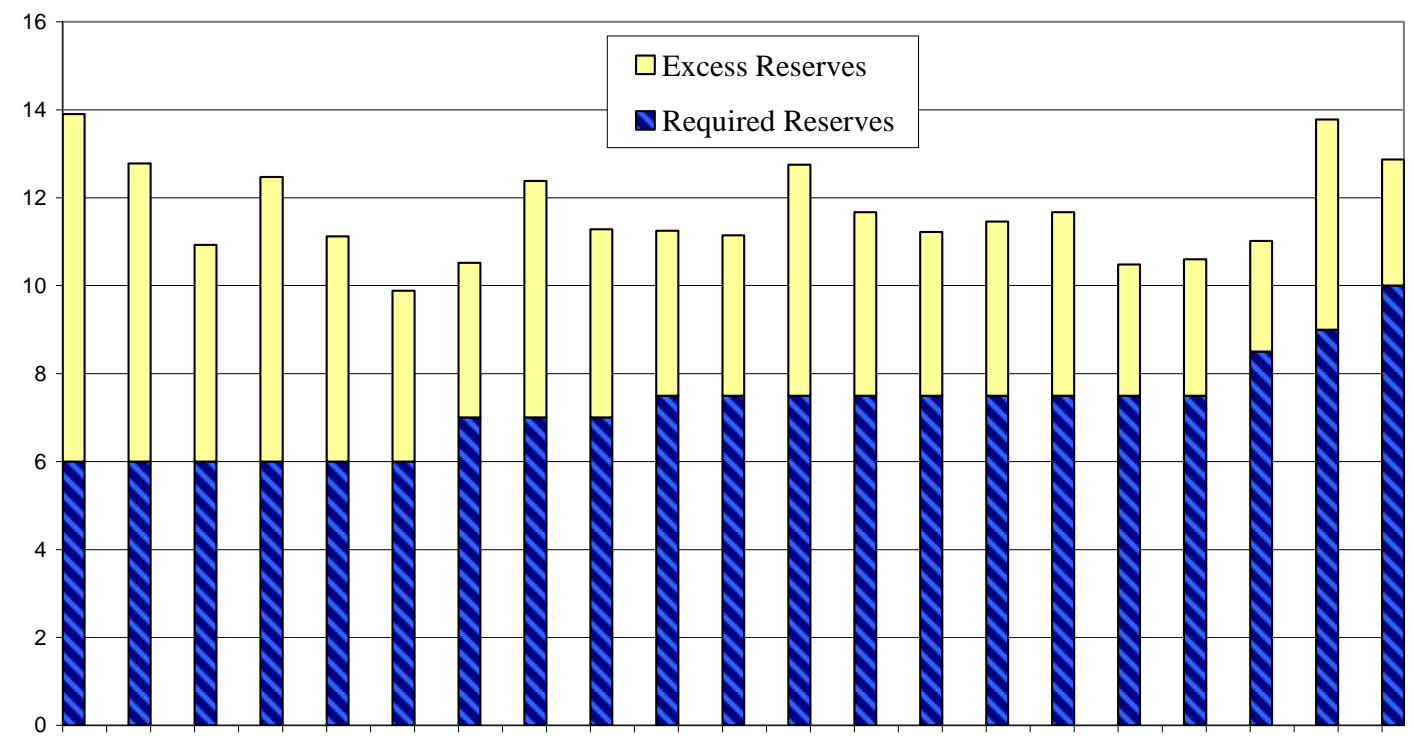

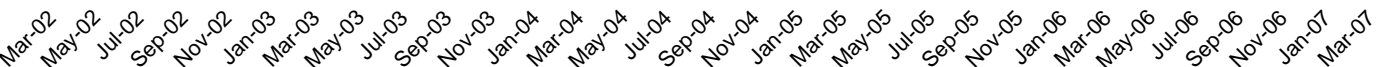

Source: CEIC

Figure 12b. Rate of Renumeration on Reserves

(in percent)

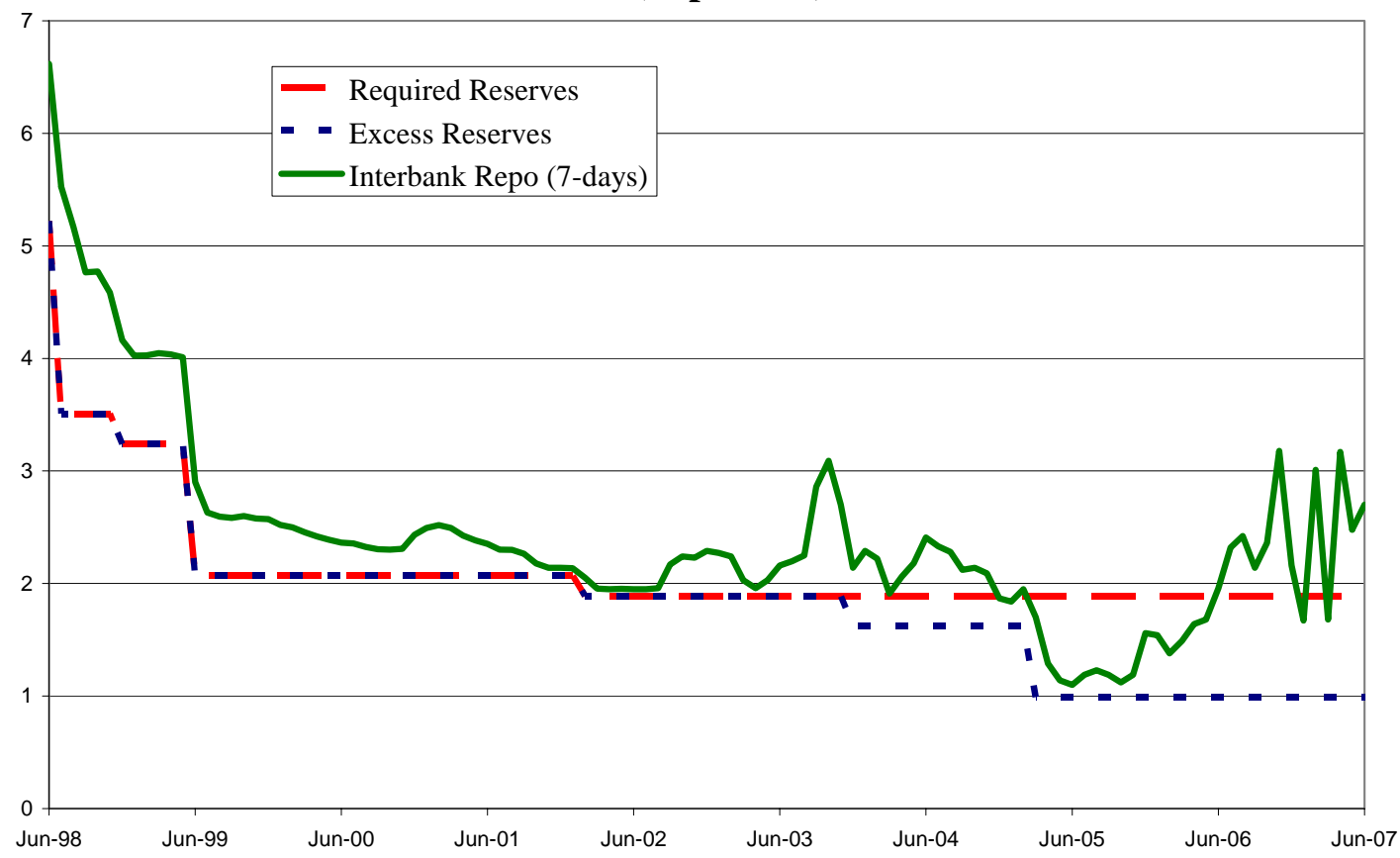

Source: CEIC 
Figure 13. Stocks of Reserves and Central Bank Bills (in billions of RMB)

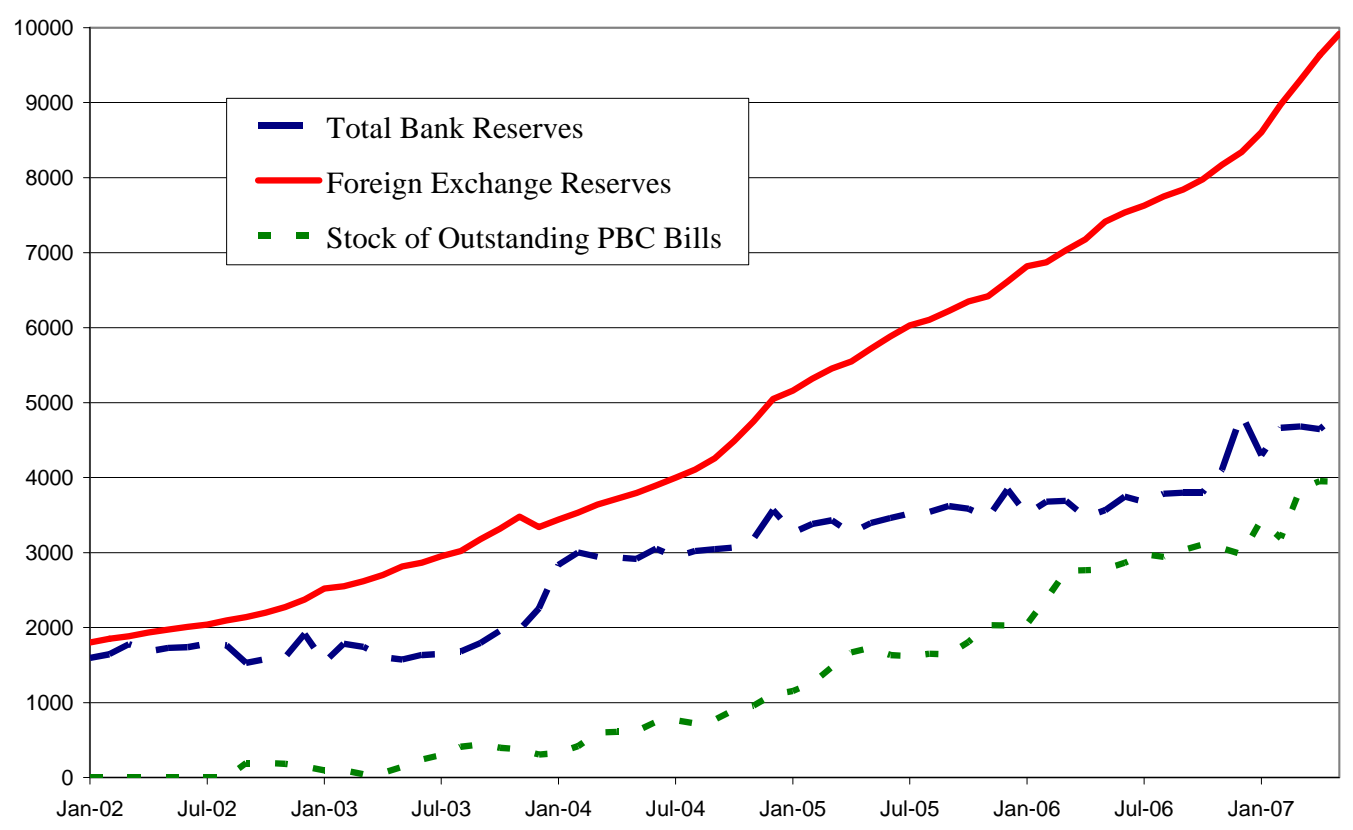

Source: CEIC and IFS

Figure 14. PBC Bill Rates vs. U.S Treasury Yields (in percent, annualized)

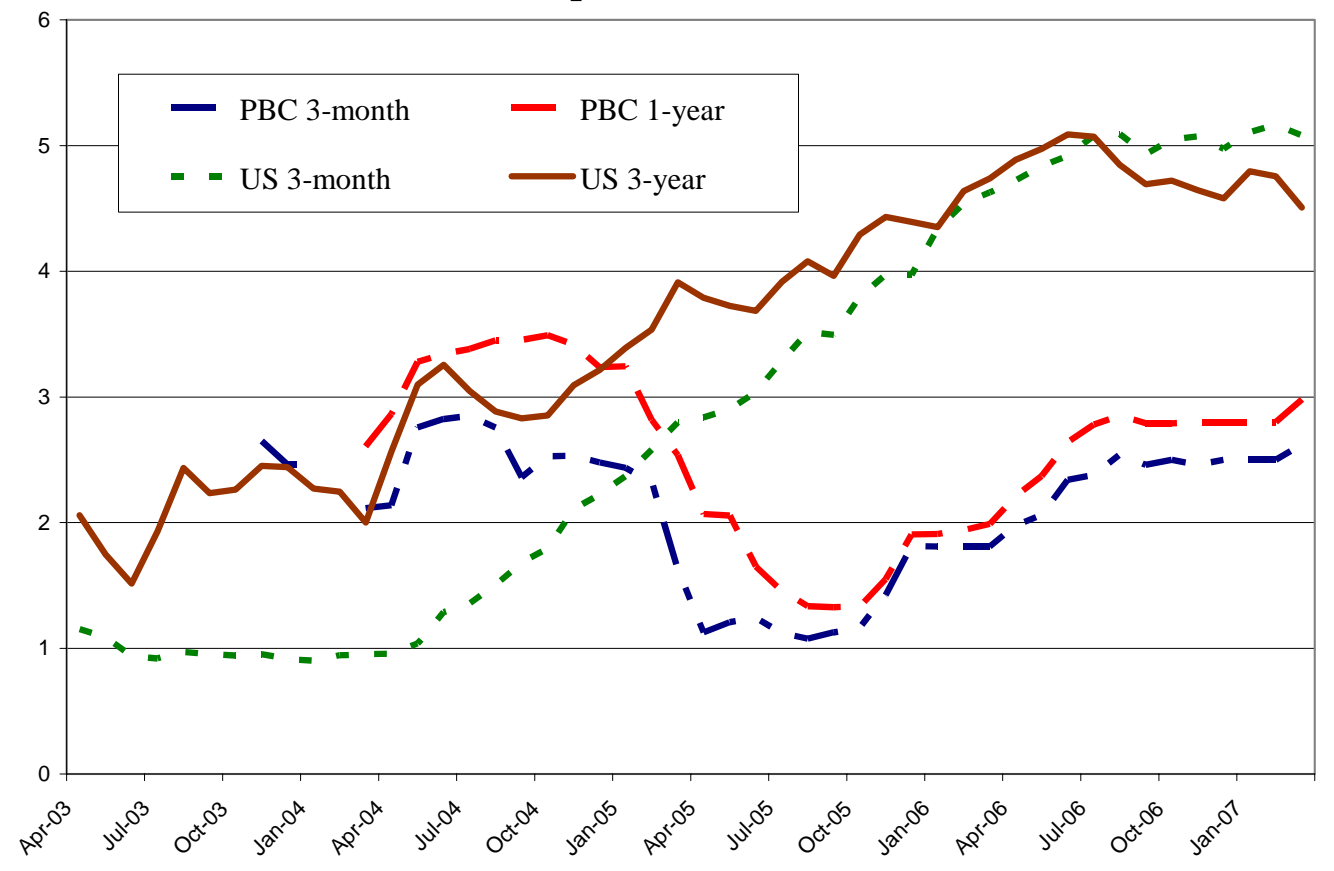

Source: CEIC, PBC and US Treasury 
Figure 15a. Stock Market Capitalization

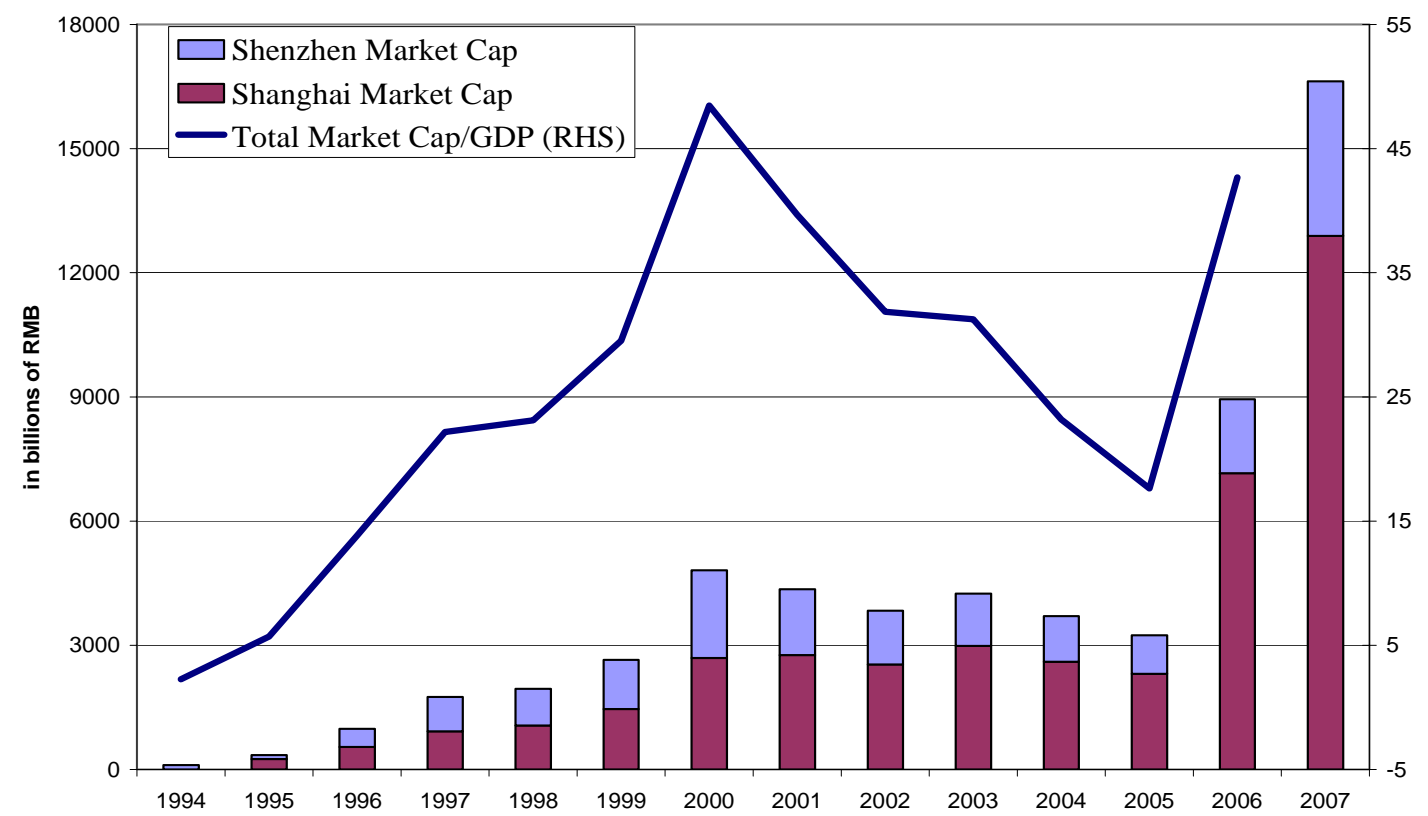

Source: CEIC and author's calculations

Note: Data for 2007 is the figure ending June 2007

Figure 15b. Stock Market Valuations

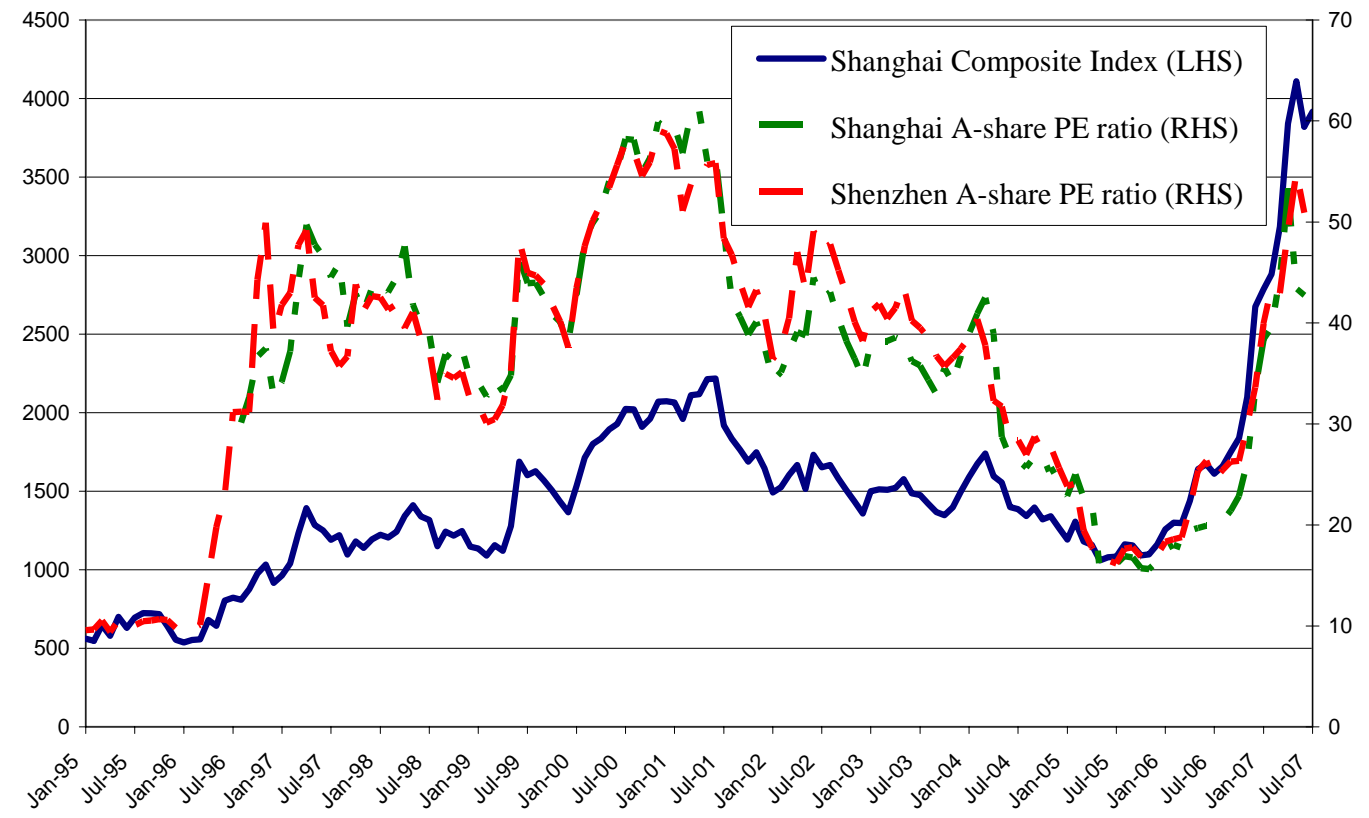

Source: CEIC 
Table 1. The Structure of Employment

\begin{tabular}{|c|c|c|c|c|c|c|c|c|}
\hline \multirow[b]{2}{*}{ Year } & \multirow{2}{*}{$\begin{array}{l}\text { Total } \\
\text { Emp. }\end{array}$} & \multicolumn{3}{|c|}{ Sectoral Employment Levels } & \multicolumn{3}{|c|}{ Sectoral Employment Shares } & \multirow{2}{*}{$\begin{array}{l}\text { Emp. Growth: } \\
\text { Sec. + Tertiary }\end{array}$} \\
\hline & & Primary & Secondary & Tertiary & Primary & Secondary & Tertiary & \\
\hline 1990 & 647 & 389 & 139 & 120 & 60.1 & 21.4 & 18.5 & \\
\hline 1991 & 655 & 391 & 140 & 124 & 59.7 & 21.4 & 18.9 & 2.2 \\
\hline 1992 & 662 & 387 & 144 & 131 & 58.5 & 21.7 & 19.8 & 4.0 \\
\hline 1993 & 668 & 377 & 150 & 142 & 56.4 & 22.4 & 21.2 & 6.1 \\
\hline 1994 & 675 & 366 & 153 & 155 & 54.3 & 22.7 & 23.0 & 5.8 \\
\hline 1995 & 681 & 355 & 157 & 169 & 52.2 & 23.0 & 24.8 & 5.5 \\
\hline 1996 & 690 & 348 & 162 & 179 & 50.5 & 23.5 & 26.0 & 4.9 \\
\hline 1997 & 698 & 348 & 165 & 184 & 49.9 & 23.7 & 26.4 & 2.5 \\
\hline 1998 & 706 & 352 & 166 & 189 & 49.8 & 23.5 & 26.7 & 1.4 \\
\hline 1999 & 714 & 358 & 164 & 192 & 50.1 & 23.0 & 26.9 & 0.5 \\
\hline 2000 & 721 & 360 & 162 & 198 & 50.0 & 22.5 & 27.5 & 1.2 \\
\hline 2001 & 730 & 365 & 163 & 202 & 50.0 & 22.3 & 27.7 & 1.3 \\
\hline 2002 & 737 & 369 & 158 & 211 & 50.0 & 21.4 & 28.6 & 1.0 \\
\hline 2003 & 744 & 365 & 161 & 218 & 49.1 & 21.6 & 29.3 & 2.8 \\
\hline 2004 & 752 & 353 & 169 & 230 & 46.9 & 22.5 & 30.6 & 5.4 \\
\hline 2005 & 758 & 340 & 181 & 238 & 44.8 & 23.8 & 31.3 & 4.8 \\
\hline 2006 & 764 & & & & & & & \\
\hline
\end{tabular}

Sources: CEIC, China Statistical Yearbook 2006, National Bureau of Statistics and author's calculations.

Notes: Primary sector covers farming, forestry, animal husbandry and fishing. Secondary sector covers industry (mining, manufacturing and energy production) and construction. Tertiary sector covers the rest. Levels are in millions of persons. 
Table 2. The Sectoral Composition of GDP Growth

\begin{tabular}{|c|c|c|c|c|c|c|c|c|c|c|}
\hline \multirow[b]{2}{*}{ Year } & \multicolumn{4}{|c|}{ GDP Growth } & \multicolumn{3}{|c|}{ Sectoral Shares in GDP } & \multicolumn{3}{|c|}{$\begin{array}{l}\text { Sectoral Contributions to } \\
\text { Aggregate GDP Growth }\end{array}$} \\
\hline & Total & Primary & Secondary & Tertiary & Primary & Secondary & Tertiary & $\underline{\text { Primary }}$ & Secondary & Tertiary \\
\hline 1991 & 9.2 & 2.4 & 13.9 & 8.9 & 17.5 & 52.6 & 29.9 & 0.4 & 6.4 & 2.4 \\
\hline 1992 & 14.2 & 4.7 & 21.1 & 12.4 & 15.8 & 55.1 & 29.1 & 0.7 & 10.1 & 3.4 \\
\hline 1993 & 13.9 & 4.7 & 19.9 & 12.2 & 14.4 & 57.3 & 28.3 & 0.7 & 10.0 & 3.3 \\
\hline 1994 & 13.1 & 4.0 & 18.4 & 11.1 & 13.1 & 59.4 & 27.6 & 0.5 & 9.7 & 2.9 \\
\hline 1995 & 10.9 & 5.0 & 13.9 & 9.8 & 12.3 & 60.6 & 27.1 & 0.6 & 7.8 & 2.6 \\
\hline 1996 & 10.0 & 5.1 & 12.1 & 9.4 & 11.7 & 61.5 & 26.9 & 0.6 & 7.0 & 2.4 \\
\hline 1997 & 9.3 & 3.5 & 10.5 & 10.7 & 11.0 & 61.9 & 27.1 & 0.4 & 6.1 & 2.7 \\
\hline 1998 & 7.8 & 3.5 & 8.9 & 8.4 & 10.6 & 62.3 & 27.1 & 0.4 & 5.3 & 2.2 \\
\hline 1999 & 7.6 & 2.8 & 8.1 & 9.3 & 10.1 & 62.4 & 27.5 & 0.3 & 4.9 & 2.4 \\
\hline 2000 & 8.4 & 2.4 & 9.4 & 9.7 & 9.5 & 62.8 & 27.7 & 0.2 & 5.6 & 2.6 \\
\hline 2001 & 8.3 & 2.8 & 8.4 & 10.3 & 9.0 & 62.8 & 28.2 & 0.3 & 5.2 & 2.8 \\
\hline 2002 & 9.1 & 2.9 & 9.8 & 10.4 & 8.4 & 63.1 & 28.5 & 0.3 & 6.0 & 2.9 \\
\hline 2003 & 10.0 & 2.5 & 12.7 & 9.5 & 7.8 & 64.1 & 28.1 & 0.2 & 7.3 & 2.5 \\
\hline 2004 & 10.1 & 6.3 & 11.1 & 10.1 & 7.5 & 64.5 & 28.0 & 0.5 & 6.9 & 2.7 \\
\hline 2005 & 10.4 & 5.2 & 11.7 & 9.8 & 7.1 & 65.1 & 27.8 & 0.4 & 7.4 & 2.7 \\
\hline 2006 & 10.7 & 5.0 & 12.5 & 11.1 & 6.7 & 65.6 & 27.7 & 0.3 & 7.5 & 2.8 \\
\hline
\end{tabular}

Source: CEIC and author's calculations.

Notes: Primary sector covers farming, forestry, animal husbandry and fishing. Secondary sector covers industry (mining, manufacturing and energy production) and construction. Tertiary sector covers the rest. 
Table 3. The Balance of Payments

(in billions of US dollars)

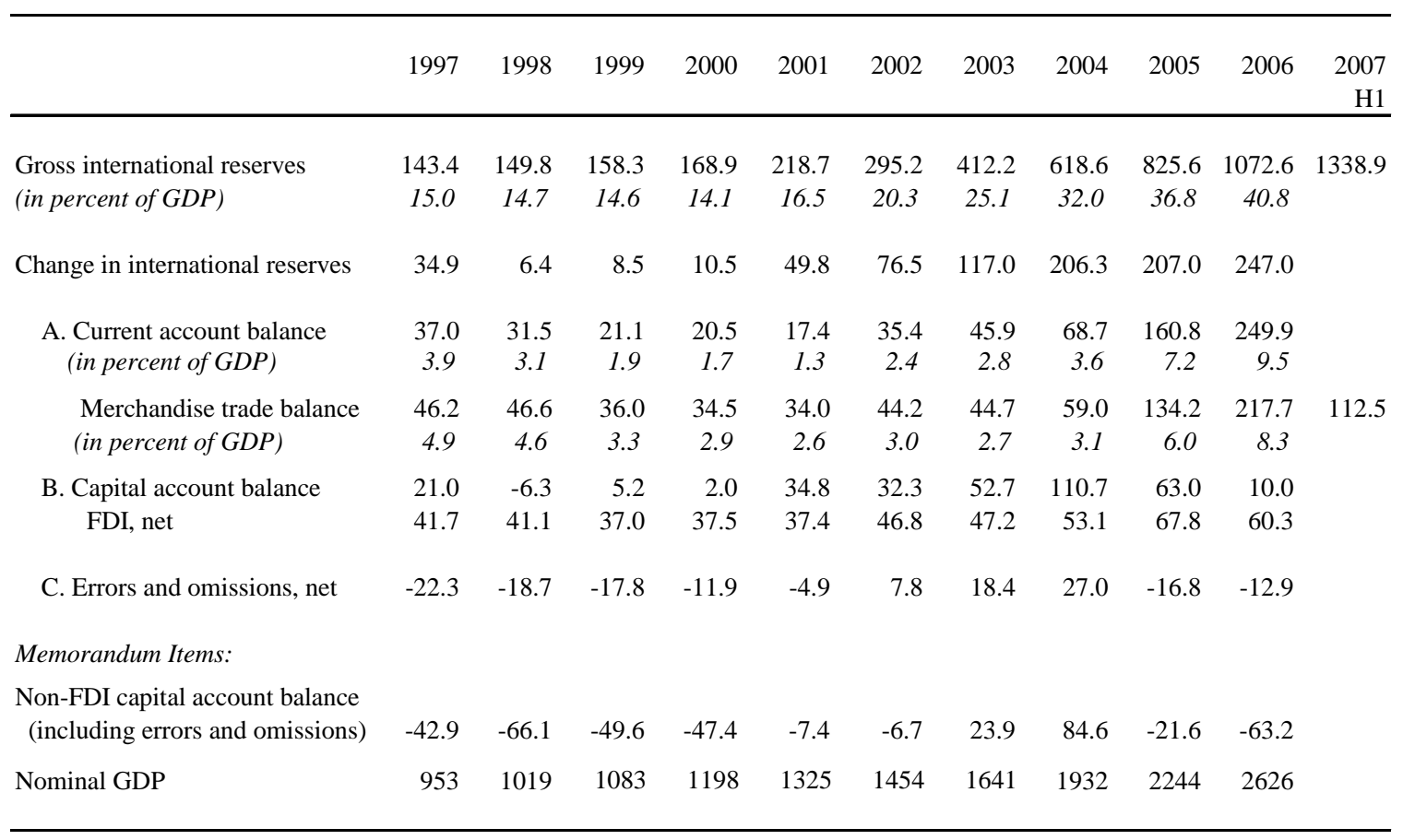

Sources : CEIC, IFS and author's calculations.

Notes: The data for 2007 are end-June data. At end-June, foreign exchange reserves stood at \$1332.6 billion. The number for gross international reserves for 2007 is an estimate. The non-FDI capital account balance is the capital account balance minus net FDI plus net errors and omissions. 
Table 4. A Decomposition of the Recent Reserve Buildup (in billions of U.S. dollars)

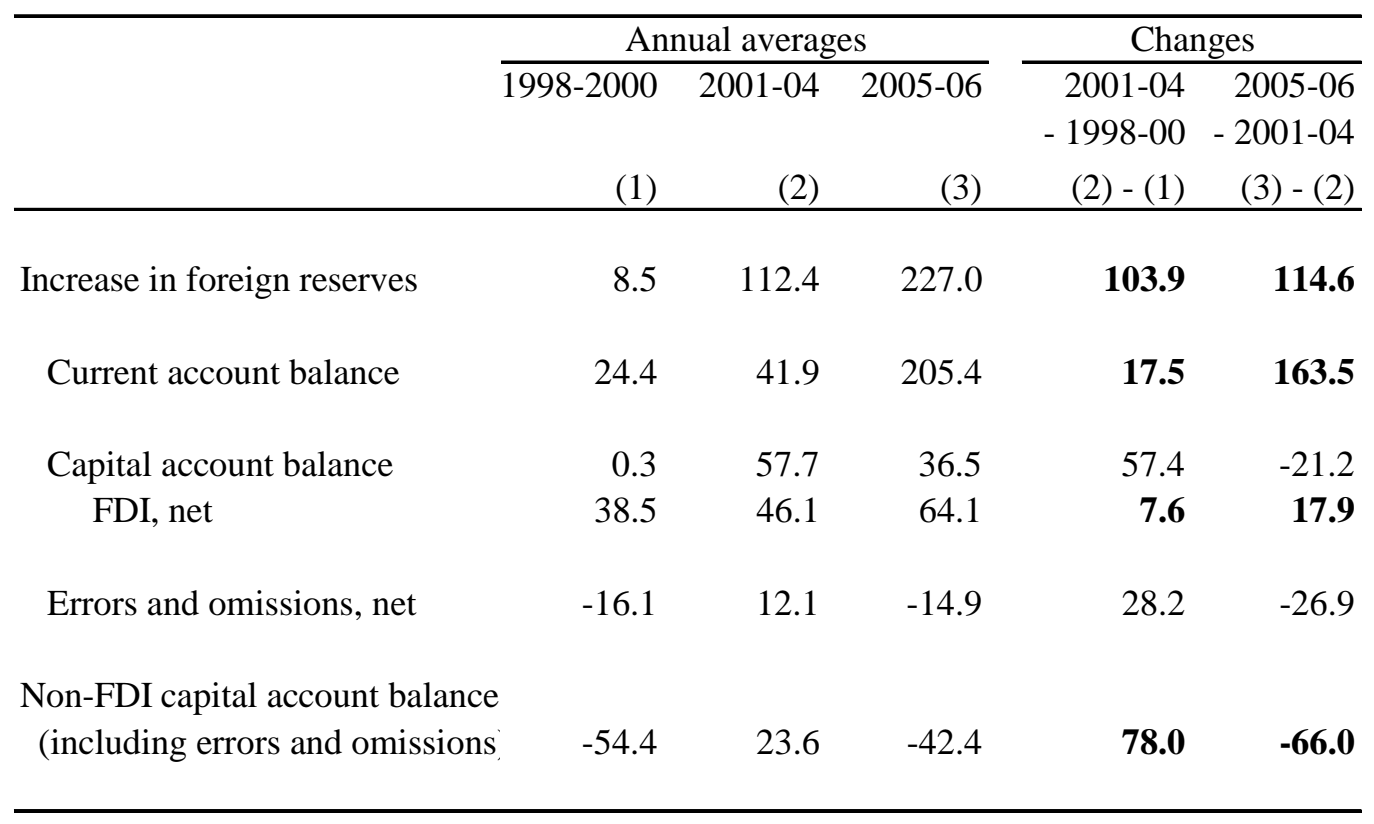

Sources: CEIC, IFS and author's calculations.

Notes: The non-FDI capital account balance is the capital account balance minus net FDI plus net errors and omissions. 
Table 5. International Investment Position

(in billions of U.S. dollars)

\begin{tabular}{lrrr}
\hline & 2004 & 2005 & $\mathbf{2 0 0 6}$ \\
\cline { 2 - 4 } Net Position & 293 & $\mathbf{4 2 3}$ & $\mathbf{6 6 2}$ \\
& & & \\
A. Assets & $\mathbf{9 3 0}$ & $\mathbf{1 2 2 3}$ & $\mathbf{1 6 2 7}$ \\
& & & \\
1. FDI & 53 & $\mathbf{6 5}$ & $\mathbf{8 2}$ \\
2. Portfolio & $\mathbf{9 2}$ & $\mathbf{1 1 7}$ & $\mathbf{2 2 9}$ \\
$\quad$ Equity & 0 & 0 & 2 \\
$\quad$ Debt & 92 & 117 & 228 \\
3. Other investment & $\mathbf{1 6 7}$ & $\mathbf{2 1 6}$ & $\mathbf{2 4 2}$ \\
4. Reserve assets & $\mathbf{6 1 9}$ & $\mathbf{8 2 6}$ & $\mathbf{1 0 7 3}$ \\
$\quad$ Foreign exchange reserves & $\mathbf{6 1 0}$ & $\mathbf{8 1 9}$ & $\mathbf{1 0 6 6}$ \\
& & & \\
B. Liabilities & $\mathbf{6 3 7}$ & $\mathbf{8 0 0}$ & $\mathbf{9 6 5}$ \\
1. FDI & & & \\
2. Portfolio & $\mathbf{3 6 9}$ & $\mathbf{4 7 2}$ & $\mathbf{5 4 4}$ \\
$\quad$ Equity & 57 & $\mathbf{7 7}$ & $\mathbf{1 2 1}$ \\
$\quad$ Debt & 43 & 64 & 107 \\
3. Other investment & 13 & 13 & 14 \\
& $\mathbf{2 1 2}$ & $\mathbf{2 5 2}$ & $\mathbf{3 0 0}$ \\
\hline
\end{tabular}

Source: State Administration of Foreign Exchange website 